\title{
Polysèmes
}

Revue d'études intertextuelles et intermédiales

\section{Knowing and Not Knowing, Moving and Not Moving, in Alain Resnais's L'Année dernière à Marienbad (1961)}

David L. Hays

\section{OpenEdition}

Journals

Electronic version

URL: http://journals.openedition.org/polysemes/3438

DOI: 10.4000/polysemes.3438

ISSN: 2496-4212

Publisher

SAIT

\section{Electronic reference}

David L. Hays, « Knowing and Not Knowing, Moving and Not Moving, in Alain Resnais's L'Année dernière à Marienbad (1961) », Polysèmes [Online], 19 | 2018, Online since 30 June 2018, connection on 20 April 2019. URL : http://journals.openedition.org/polysemes/3438; DOI : 10.4000/polysemes.3438

This text was automatically generated on 20 April 2019.

Polysèmes 


\title{
Knowing and Not Knowing, Moving and Not Moving, in Alain Resnais's L'Année dernière à Marienbad (1961)
}

\author{
David L. Hays
}

In Alain Resnais's film L'Année dernière à Marienbad (1961), a male character, known conventionally as X, confronts a female character, A, claiming that the two met one year before and agreed to depart together. ${ }^{1}$ According to X, A asked for a delay of one year, and he has now returned to take her away. A dismisses X's claims, but the tenor of her subsequent reactions varies significantly-from cool confidence, to confusion, to terrormaking interpretation uncertain. Is she trying to get out of an arrangement of which she is fully aware, or is she being destabilized by X's relentless pursuit? As proof of their encounter, $\mathrm{X}$ eventually presents A with a photograph-one he says he took himself-in which she appears sitting on a bench in a garden, leaning back slightly, seemingly laughing (fig. 1). ${ }^{2} \mathrm{He}$ asks if she recognizes it, and she replies:

A: Yes, I do. No, I don't. I don't know. I don't remember.

$\mathrm{X}$ : You know who took it.

A: You're lying.

X: It was last year. I had to insist on taking it. You said it would make you uneasy.

A: Yes, that's true. I was right. ${ }^{3}$ 


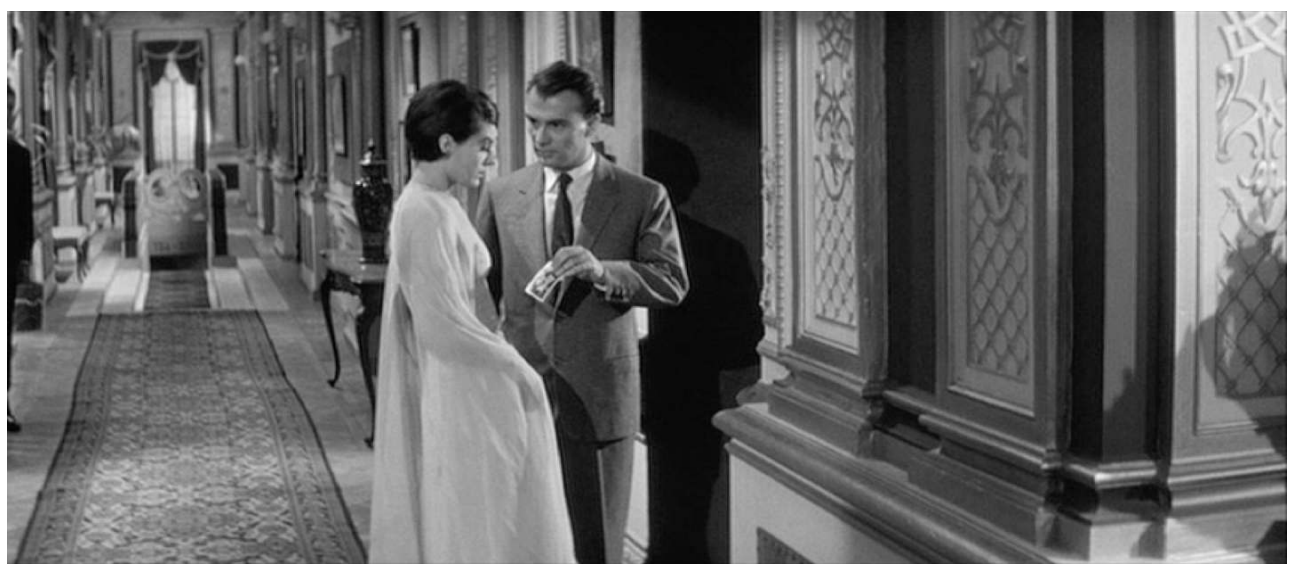

Fig. 1: Alain Resnais, L'Année dernière à Marienbad (1961)

2 A later admits that the photo represents her-when discussing it with $M$ (a man who seems to be her guardian or companion), she remarks, "it's an old photo of me"-but she discounts X's claims for it. Even so, X persists, and A ultimately acquiesces to his demand. At the end of the film, they depart together-to where is not specified $-{ }^{4}$ and it remains unclear whether A is fulfilling her end of the bargain or being misled.

3 At a superficial level, the viewer of Marienbad is challenged to discern what "really" happened "last year"-that is, to find its secret narrative or key, as in a mystery- ${ }^{5}$ although the writer, Alain Robbe-Grillet, claimed to have composed the scenario without such an underpinning, abandoning the conventional, story-based approach (Robbe-Grillet 9). Through content and editing, the script, sound score, and images cultivate a sense of the film as a stream of consciousness, or a confluence of several such streams, in which observations, memories, and fantasies co-mingle. ${ }^{6}$ The "mental origin" of the film could be attributed to any one of its characters (however unreliable), a combination of characters, or an unseen figure or figures, or it could be discounted altogether. Of course, the viewer's own observations, memories, and fantasies help constitute the film and its meanings. In the meanwhile, elements and situations within the film invite interpretation but offer no clear solutions. For example, $\mathrm{X}$ and $\mathrm{M}$ are clearly pitted against each other. At moments, the antagonism between them seems a matter of life and death-but which of them represents life, and which represents death? After yet again losing to $\mathrm{M}$ in a mathematical Nim game, $X$ places four game pieces back on the table, not from where he took them but in a new pattern, linking with two already in place to form a Christian cross facing $\mathrm{M}$ (fig. 2). Is it a sign that $\mathrm{X}$ has died, or is it an apotropaic device, implying that $\mathrm{M}$ is a vampire-or, the Devil? As an interloper whose desire is to take A away, $\mathrm{X}$ could be death, but he could also be an Orphic figure seeking to redeem A from an underworld ruled by M. In Henrik Ibsen's play Rosmersholm (1886)-alluded to within Marienbad by a theatrical play called Rosmer -a sequence of revelations causes understanding of past and present to be revised repeatedly, and a man and woman who have abandoned Christianity, tradition, and ethics leave their country seat around midnight to commit suicide together in a millstream. But is that departure-like the one at the end of Marienbad, for which it seems a clear precedent-tragedy or salvation? 


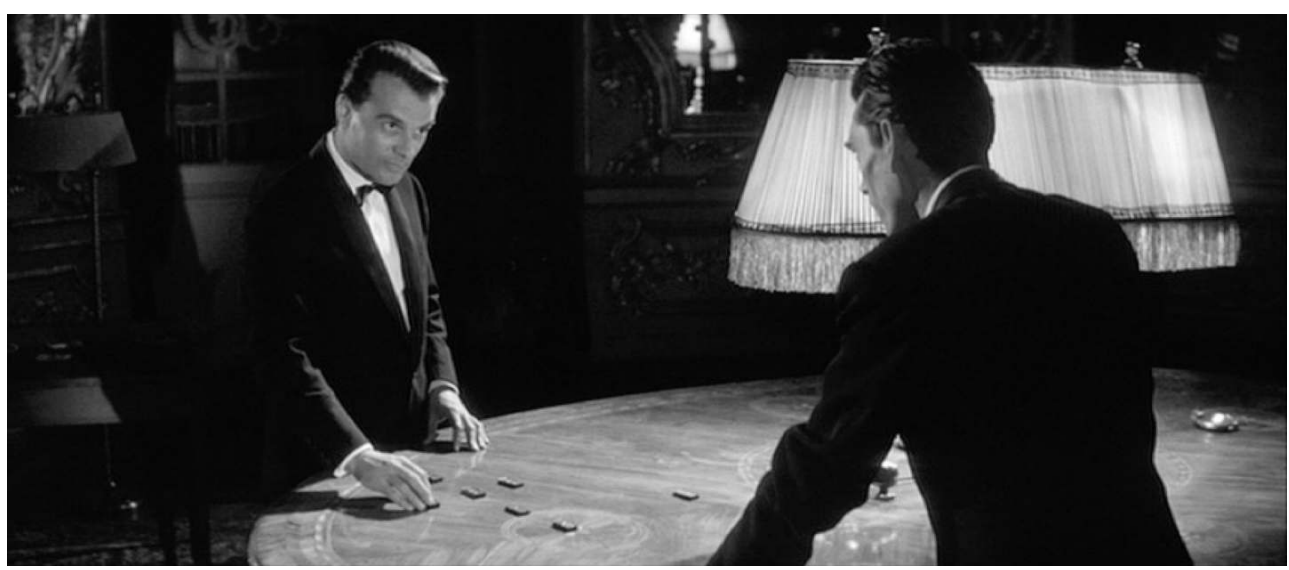

Fig. 2: Alain Resnais, L'Année dernière à Marienbad (1961)

Among the many elements within Marienbad, the photograph is of special interest because of how its credibility relates to trauma, a major theme in the film. In 1958, a year before Resnais and Robbe-Grillet began to collaborate on Marienbad (Robbe-Grillet 7), influential film theorist and critic André Bazin published an essay on the "ontology of the photographic image". ' According to Bazin, photography "derives an advantage" (Bazin 7) -a credibility-from its mechanical aspect: the process through which each object gives form to its own representation. Indexicality guarantees objectivity: "In spite of any objections our critical spirit may offer, we are forced to accept as real the existence of the object reproduced, actually re-presented, set before us, that is to say, in time and space" (8). According to that logic, photography bridges past and present, disrupting the perpetual immediacy of the here and now. Photographs and other indexical media, including films, therefore have uncanny power. In the Christian tradition, for example, religious icons transmit sacredness through tangible form. ${ }^{8}$ Similarly, images of horrorsuch as the footage of wartime atrocities incorporated into Resnais's film Nuit et brouillard (1955) - put viewers literally in touch with dark realities. ${ }^{9}$

5 In Marienbad, the photograph structures an uncanny encounter between A (in the present) and $\mathrm{A}$ (in the past). $\mathrm{X}$ asserts that the image was taken at Frederiksbad, but when A replies that she has never been to Frederiksbad, he admits that it could have been taken elsewhere-“At Karlstadt. At Marienbad. At Baden-Salsa. Or even here in this salon". The last of those suggestions recasts the photograph as pure imagination, since the image shows a garden, not an interior space. Yet, as an indexical image, and within the conceptual structure of the film, it is not pure imagination, and $\mathrm{X}$ relies on that "advantage" when asserting a connection to A. Otherwise, his claims for the image have no standing. The photograph shows A's whole body, but what can be seen of the surroundings-a bench, some lawn and clipped shrubs, the lower part of a statue, and trees in the distance-is generic to classical, French-style gardens (fig. 3). Consequently, the specific context of the photograph is not apparent-even, perhaps, to A. Also, $\mathrm{X}$ does not appear in the image, and its authorship is not marked. Therefore, it fails to prove that $\mathrm{X}$ and $\mathrm{A}$ have met before, let alone that an agreement was made between them. The photograph proves only that A existed at some moment in the past-a significant fact, to be sure, but one not sufficient to X's claims. 


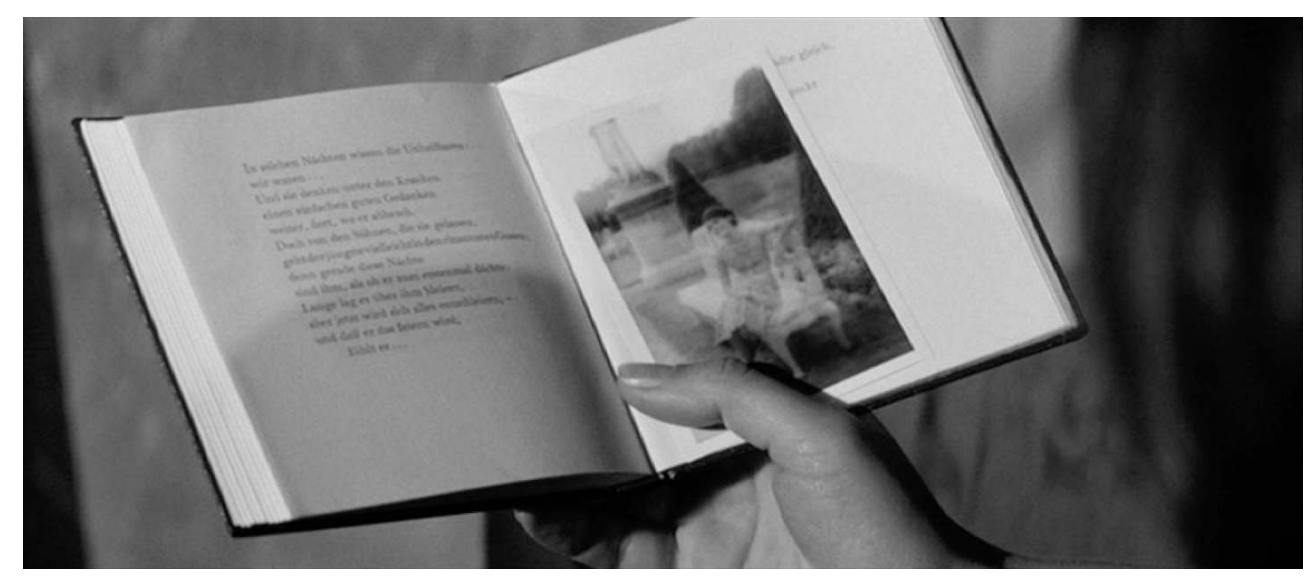

Fig. 3: Alain Resnais, L'Année dernière à Marienbad (1961)

In the context of X's relentless assertions, the photograph would be disruptive if it confirmed what $\mathrm{A}$ knew but wished to deny: that something happened between $\mathrm{X}$ and her "last year". It would also be disruptive if A were confident that nothing had happened, yet the image implied a connection, even without proving one. But A's varied responses to the photograph suggest that it is traumatizing because it locates her not in uncertainty but at the intersection of knowing and not knowing. She seems at once to know and not to know whether something happened "last year", and that condition confounds her in the threefold senses of surprising her, confusing her, and defeating her. As Cathy Caruth has written, "If Freud turns to literature to describe traumatic experience, it is because literature, like psychoanalysis, is interested in the complex relation between knowing and not knowing. And it is at the specific point at which knowing and not knowing intersect that the language of literature and the psychoanalytic theory of traumatic experience precisely meet" (3).

7 In Caruth's understanding, trauma is a condition of aporia-meaning, of "unresolvable paradox". ${ }^{10}$ In Marienbad, the photograph structures an encounter between A (in the present) and A (in the past), and that experience both unifies and divides her. According to Bazin, the photographic image is at once a representation and the thing represented:

The photographic image is the object itself, the object freed from the conditions of time and space that govern it. No matter how fuzzy, distorted, or discolored, no matter how lacking in documentary value the image may be, it shares, by virtue of the very process of its becoming, the being of the model of which it is the reproduction; it is the model. (8)

If, as Bazin suggests, the photograph of A is A herself, then viewing the photograph is both grounding and destabilizing, a condition of knowing and not knowing. If the credibility of the image is rooted in its indexicality, to which A admits, then her presence as a "central image" is both her only reality and her other reality-an unresolvable paradox that constitutes its traumatic power.

9 According to filmmaker and theorist Jean Epstein, cinematic identity is "circonscrite approximativement par des probabilités" (22) and, therefore, neither stable nor autonomous. As a paradigm of that condition, Epstein described actress Mary Pickford's legendary disappointment upon seeing her own screen image for the first time: "À la suite de sa première expérience cinématographique, s'il avait plu à Mary Pickford d'affirmer: je pense, donc je suis, il lui aurait fallu ajouter cette grave restriction: mais je ne sais pas qui je suis" (22). In Marienbad, that intersection of knowing and not knowing is 
a trauma experienced by A. When A reflects on the photograph of herself purportedly taken "last year," she is Mary Pickford, "[i]ncrédule, déçue, scandalisée" (22).

What happened "last year"-if anything happened at all-and how that connects to a pact to depart together are never clarified. Several sequences in Marienbad suggest a violent encounter-specifically, that X raped A. ${ }^{11}$ But the trauma is not what happened in the past but rather the way the past recurs and disrupts, like a haunting. Building on Freud's account in Beyond the Pleasure Principle, Caruth has described trauma as "the response [my emphasis] to an unexpected or overwhelming violent event or events that are not fully grasped as they occur, but return later in repeated flashbacks, nightmares, and other repetitive phenomena" (91). In that understanding, trauma is "a wound inflicted not upon the body but upon the mind" (3), a "breach in the mind's experience of time, self, and the world", following "an event that [...] is experienced too soon, too unexpectedly, to be fully known and is therefore not available to consciousness until it imposes itself again, repeatedly, in the nightmares and repetitive actions of the survivor" (4). Without knowing what, if anything, happened "last year", the only element verifiably "of the past" within the conceptual framework of Marienbad is the photograph. Consequently, A's repeated encounters with the photograph-as revealed to her by X (see fig. 1), as laid over a page in an open book (see fig. 2), as a subject of interrogation by M (fig. 4), as a cache of many copies discovered inside a desk drawer (fig. 5), and as sixteen prints laid out in the form of a Nim game (fig. 6) - constitute the trauma. Embodied by the photograph, A's condition of knowing and not knowing allows the past to become active, blurring the distinction between memory and perception and foreclosing her ability to "pass beyond [her]self". ${ }^{12}$

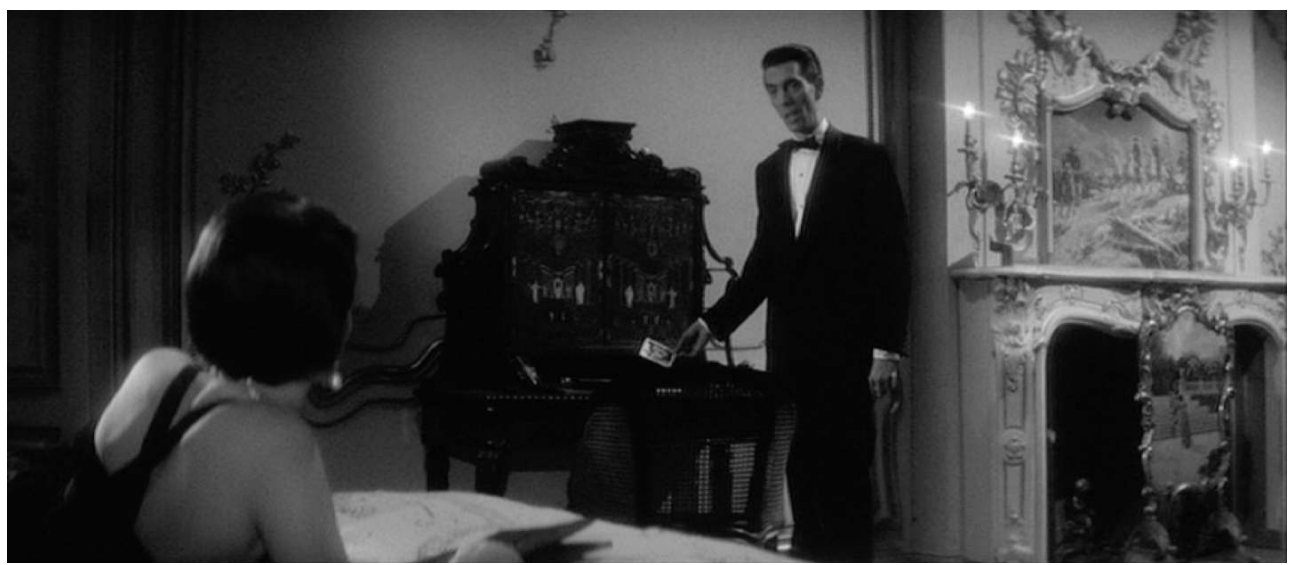

Fig. 4: Alain Resnais, L'Année dernière à Marienbad (1961) 


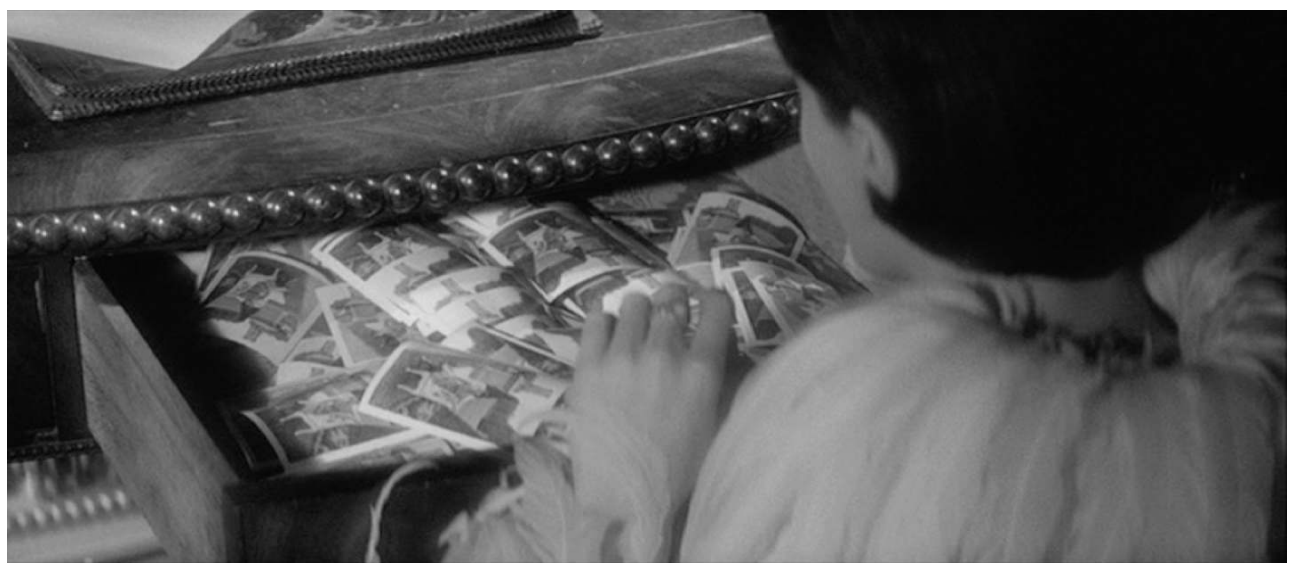

Fig. 5: Alain Resnais, L'Année dernière à Marienbad (1961)

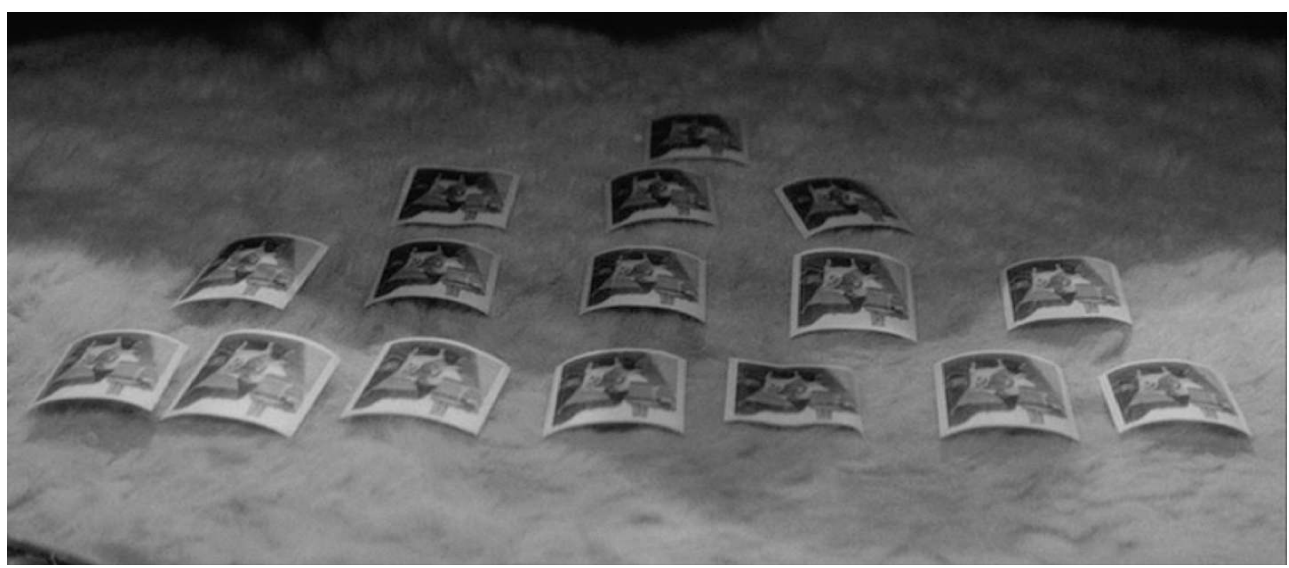

Fig. 6: Alain Resnais, L'Année dernière à Marienbad (1961)

11 That condition is also powerfully manifest when A inches across the front of a mirrored wall, turned towards her reflection with her hands cupped about her face, as if trying desperately to peer deeper, beyond its surface. Writing of mirror-images in modern cinema, philosopher Gilles Deleuze noted the indiscernibility and reversibility of their virtual and actual aspects, a condition ascribed to the "crystal-image, or crystalline description" more broadly: "The mirror-image is virtual in relation to the actual character that the mirror catches, but it is actual in the mirror which now leaves the character with only a virtuality and pushes him back out-of-field. [...] The actual image and its virtual image thus constitute the smallest internal circuit [...]. Distinct, but indiscernible, such are the actual and the virtual which are in continual exchange" (70).

Although rarified in its superficial aspects, A's predicament in Marienbad evoked a general sense of cultural crisis in the wake of World War II. To Resnais, modernity seemed to have atomized culture, and he used film to explore situations in which that crisis was playing itself out: from cultural institutions, such as museums and libraries, to sites of mass atrocity, such as concentration camps and places of nuclear attack. In 1959, film director and critic Jacques Rivette described Resnais's work as a search for "the lost secret of humanity", linked to a need "to try to reassemble the scattered fragments of the universal culture that is being lost", ${ }^{13}$ but his work is also pervaded by a sense that matter itself has been transmuted and that new forms of representation must therefore be developed. In keeping with that idea, Resnais's films up to and including Marienbad-from short works such as Les Statues meurent aussi (1953), Nuit et brouillard (1955), and Toute la 
mémoire du monde (1956) to his first feature-length film, Hiroshima mon amour (1959)explore and test, over and over, the relationship among representation, history (interpretation of the past), and the human body. ${ }^{14}$

13 For example, in Hiroshima mon amour, the film Resnais completed just before making Marienbad, that relationship is probed in the flashback sequence, which occurs early in the film. ${ }^{15}$ Presented from the point of view of the heroine, a French actress working in Hiroshima, the flashback relates images of two hands: one "in the present" belonging to her sleeping, Japanese lover-an architect living in Hiroshima-and the other "of the past" belonging to her dying, German lover-a soldier killed in France about fifteen years before (fig. 7 and 8 ). The hands are matched graphically across cuts; each is laid flat, palm up, with fingers curled. Both images appear still, like photographs, except that the fingers twitch slightly, and the shot of the German soldier's hand-which appears closer upsuddenly pans right to reveal the heroine embracing him, her face marked with his blood. Like A viewing the photograph in Marienbad, the heroine of Hiroshima here confronts an unanticipated image of herself in the past. Predicated on formal resemblance, the relating of hands manifests a trauma, in which a "past" image interrupts "present" vision. ${ }^{16}$ Robbe-Grillet spoke of this sequence as a representation of "réalisme mental", by which he meant the unmarked presence of internal and external images in the mental process (i.e., stream of consciousness) (Labarthe and Rivette 10). ${ }^{17}$ Resnais agreed that the sequence represents a "victoire du réalisme" (10), its form breaking sharply with the cinematic conventions for flashbacks. ${ }^{18}$

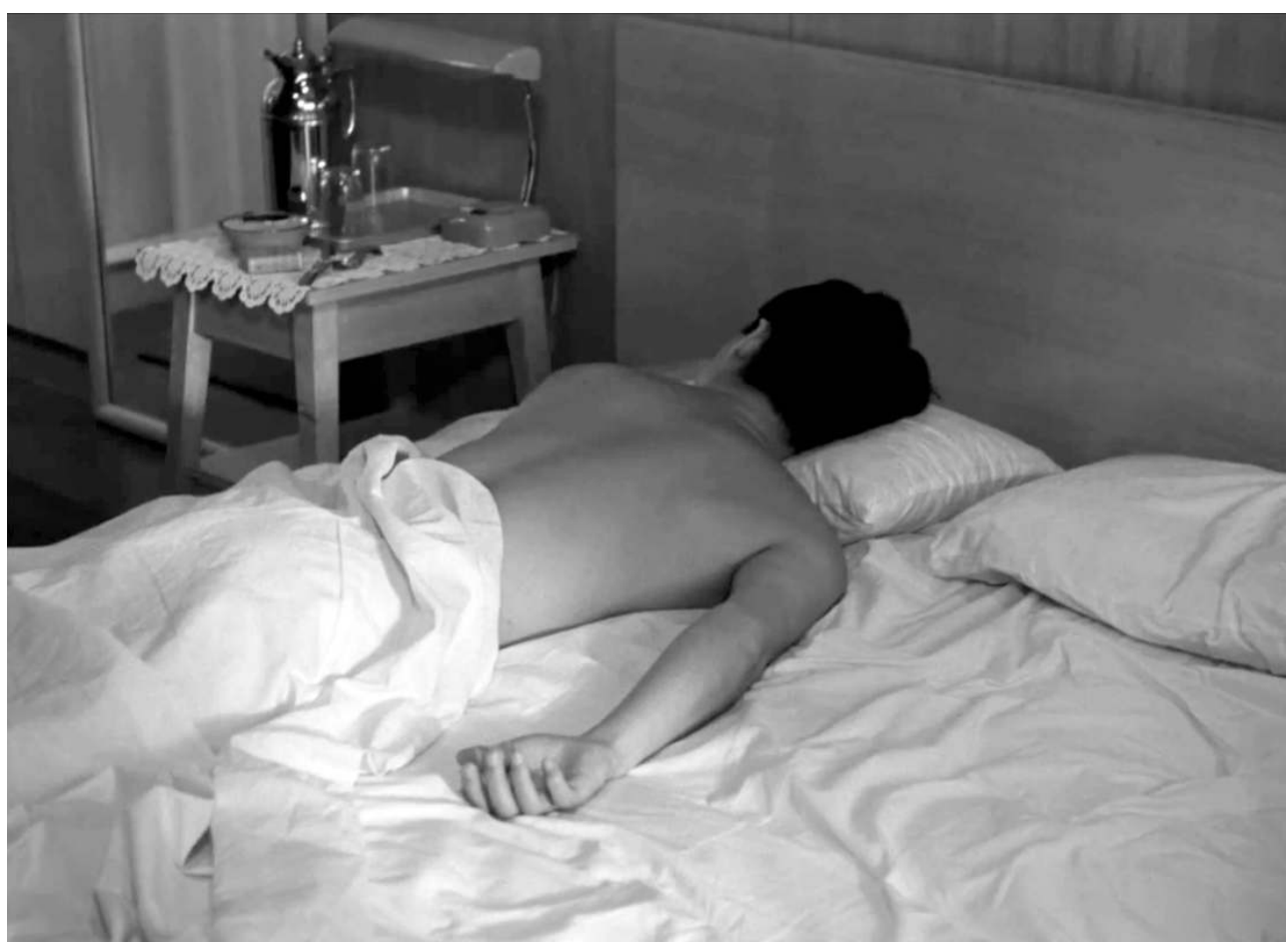

Fig. 7: Alain Resnais, Hiroshima mon amour (1959) 


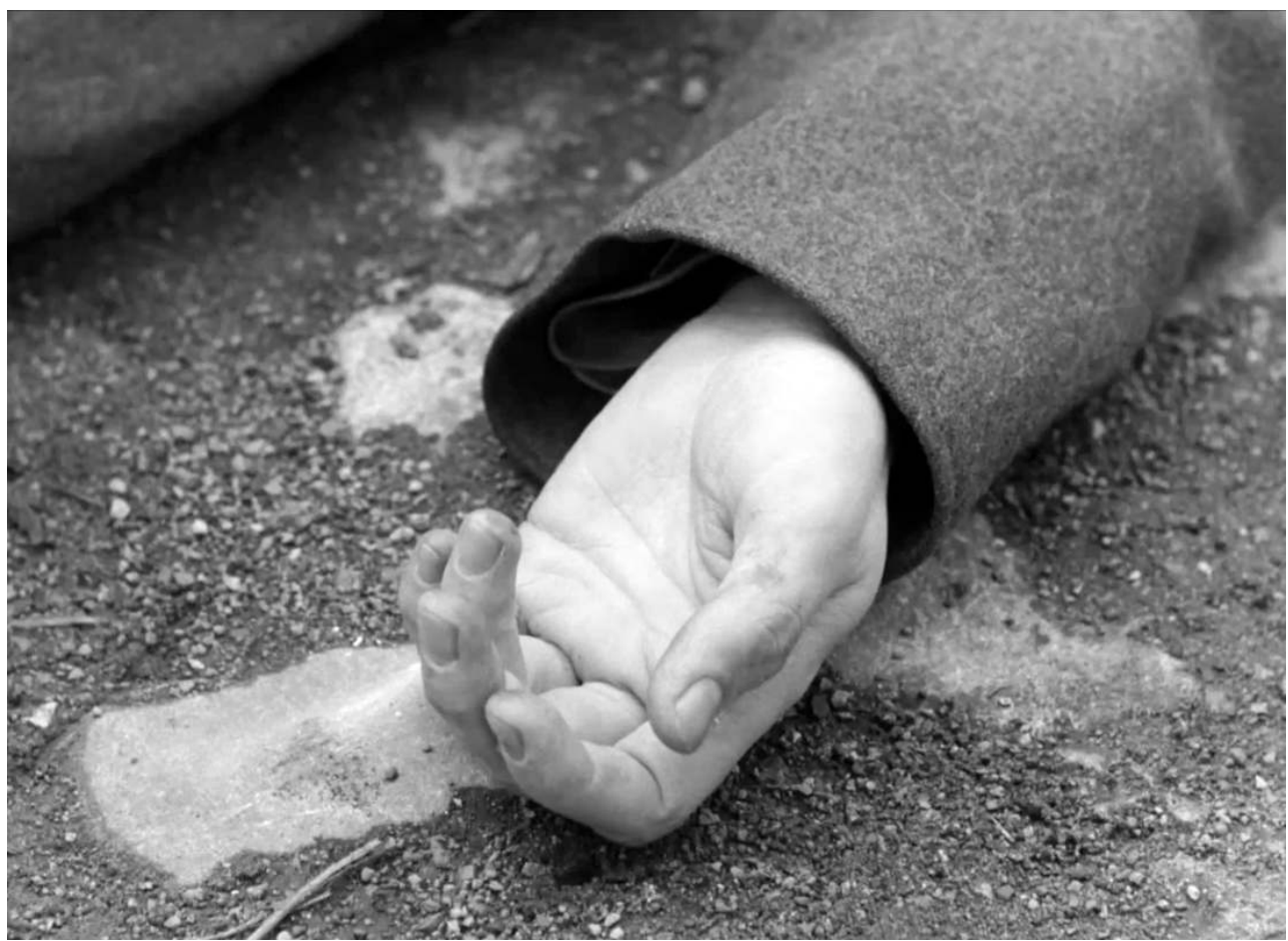

Fig. 8: Alain Resnais, Hiroshima mon amour (1959)

In Hiroshima, graphic matching of bodily images structured a device through which to relate distant times and places, but flashbacks were out of the question in Marienbad, given the ambiguous treatment of time there, ${ }^{19}$ and bodily images were used instead to subvert the credibility of filmic space. For example, the setting of Marienbad is a baroque palace (repurposed as a luxurious hotel) and French-style garden- ${ }^{20}$ historic, spatial types known for combining elaborate decorative schemes with highly rationalized plans. Within that context, a large, presumably immovable sculpture of a man and woman in classical dress, with a dog at their feet, appears several times in the film but in differing garden situations, contradicting spatial logic. The first two instances are in an engraved view of a palace and garden, displayed on a wall inside the palace-hotel (fig. 9). ${ }^{21}$ The sculpture appears in the right foreground of the print, its back to the viewer and facing the palace across the large parterre garden.

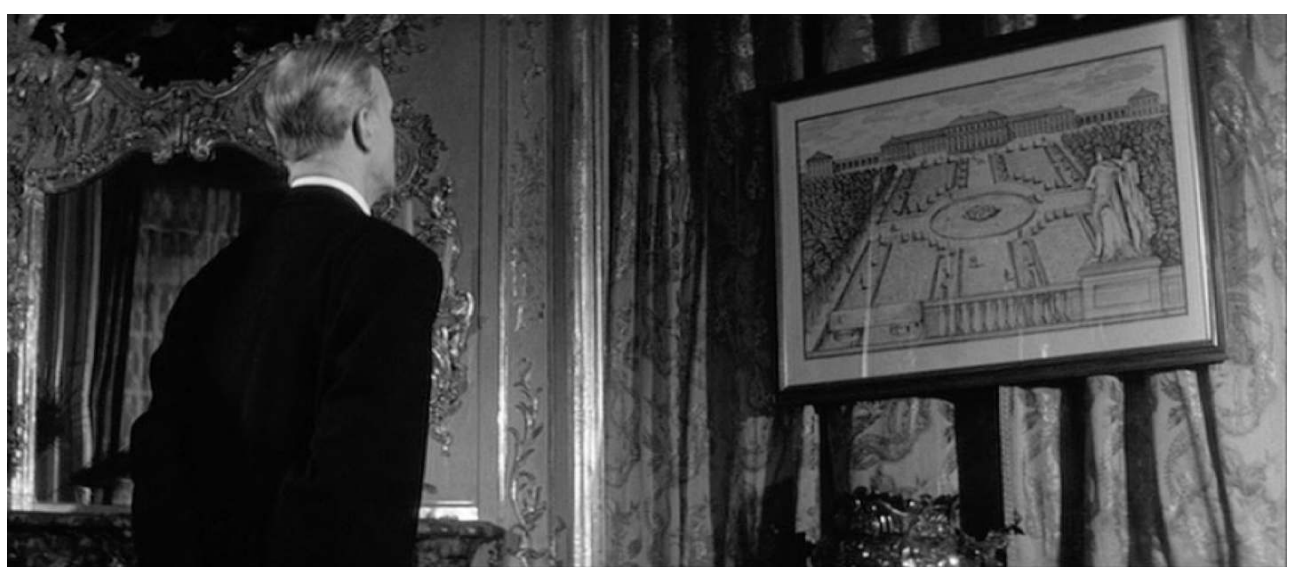

Fig. 9: Alain Resnais, L'Année dernière à Marienbad (1961) 
However, in its first physical appearance in the film-an unsignaled long shot, lasting three seconds, during which the soundtrack cuts out completely-the sculpture stands on a low plinth near the corner of a garden terrace, facing the viewer, with its back to a canal and cascades pulsing rhythmically beyond (fig. 10). That image anticipates a sequence that begins a couple of minutes later, in which $\mathrm{X}$ describes the sculpture to $\mathrm{A}$ in an attempt to jog her memory, claiming that they had looked at it together "the first time he had seen her", alone, in "the gardens at Frederiksbad". No images of the sculpture or its setting are visible in that sequence, but, five minutes later, the garden appears, and $\mathrm{X}$ describes both A and the sculpture. A appears in the scene, in front of a stone balustrade and facing a large parterre garden, and she seems to follow X's verbal cues (fig. 11). In sync with his account, the camera turns left to reveal the sculpture close by, overhanging the balustrade, with its back to the parterre garden. The shot then cuts to a low, back view of the sculpture, with the camera moving slowly upwards to reveal that it now faces a canal-though not the setting seen earlier (fig. 12). After a brief hold, the image cuts to an eye-level, frontal view of the sculpture, once again with its back to the parterre garden (fig. 13). The camera tracks right while panning left, keeping the sculpture in the center of the shot. Then, a crane shot, a close-up, and a long shot show the sculpture from its right and left sides, including sky and trees but no other context, as if the figures were standing in a park (fig. 14). In the next and final shot of the sequence, the sculpture appears once again near the corner of the garden terrace, with $\mathrm{X}$ and $\mathrm{A}$ discussing it nearby (fig. 15).

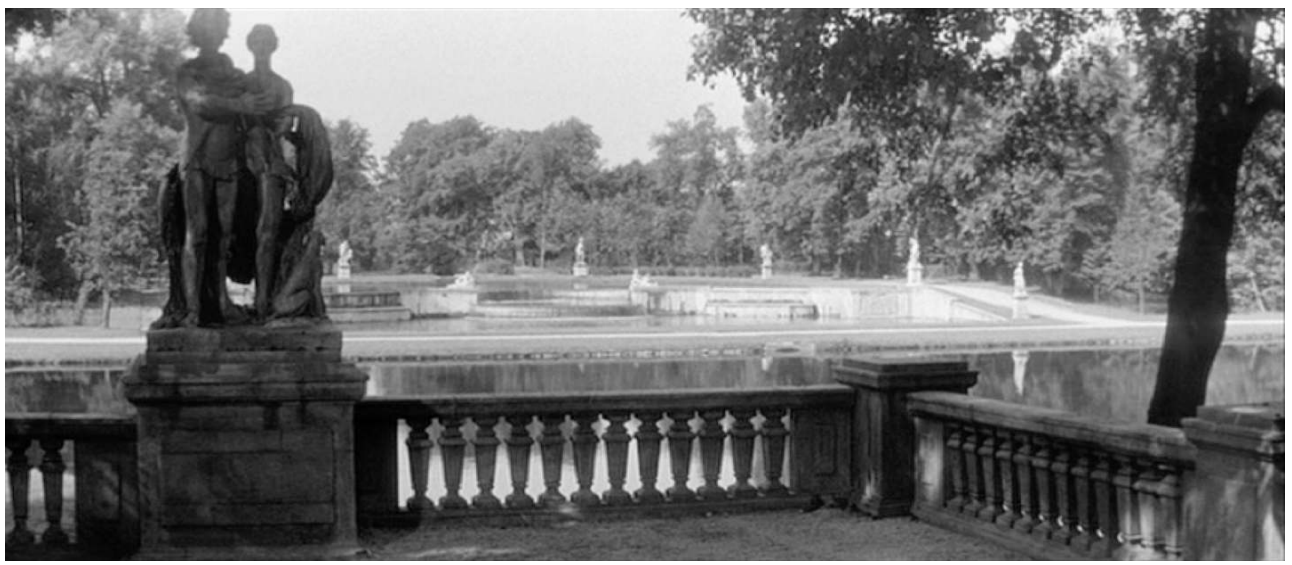

Fig. 10: Alain Resnais, L'Année dernière à Marienbad (1961)

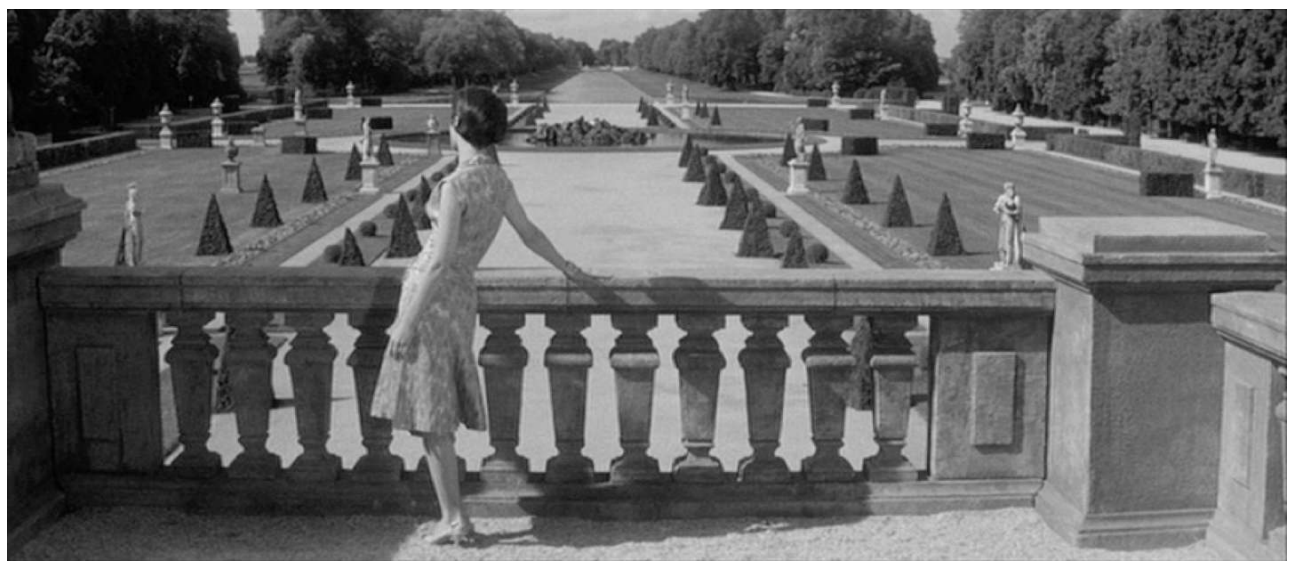

Fig. 11: Alain Resnais, L'Année dernière à Marienbad (1961) 


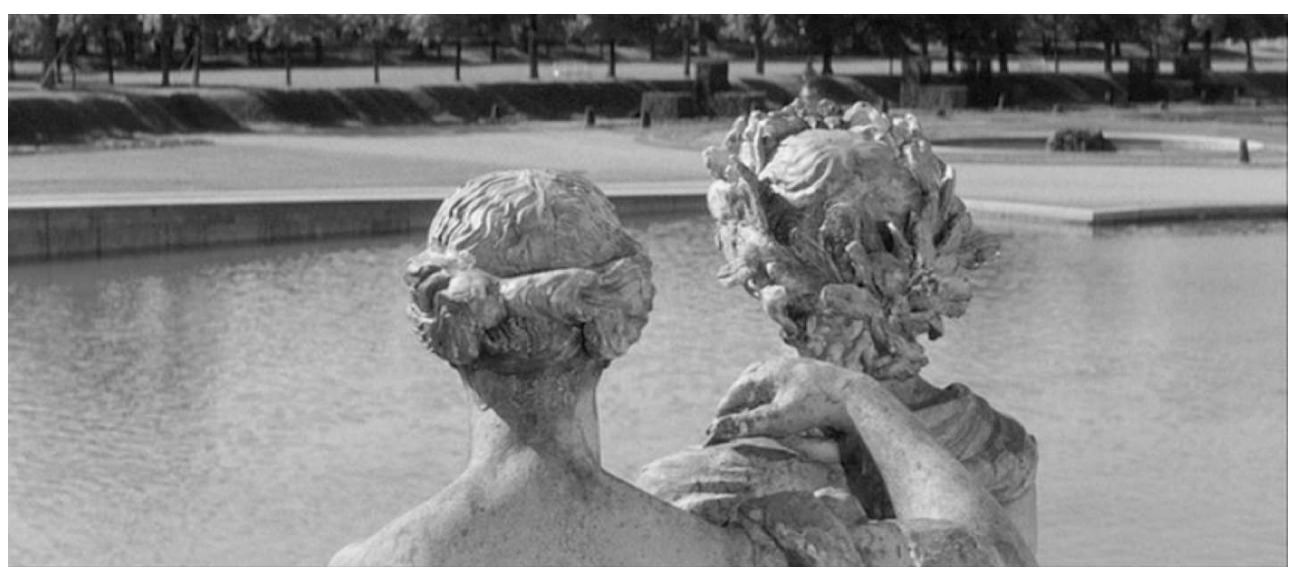

Fig. 12: Alain Resnais, L'Année dernière à Marienbad (1961)

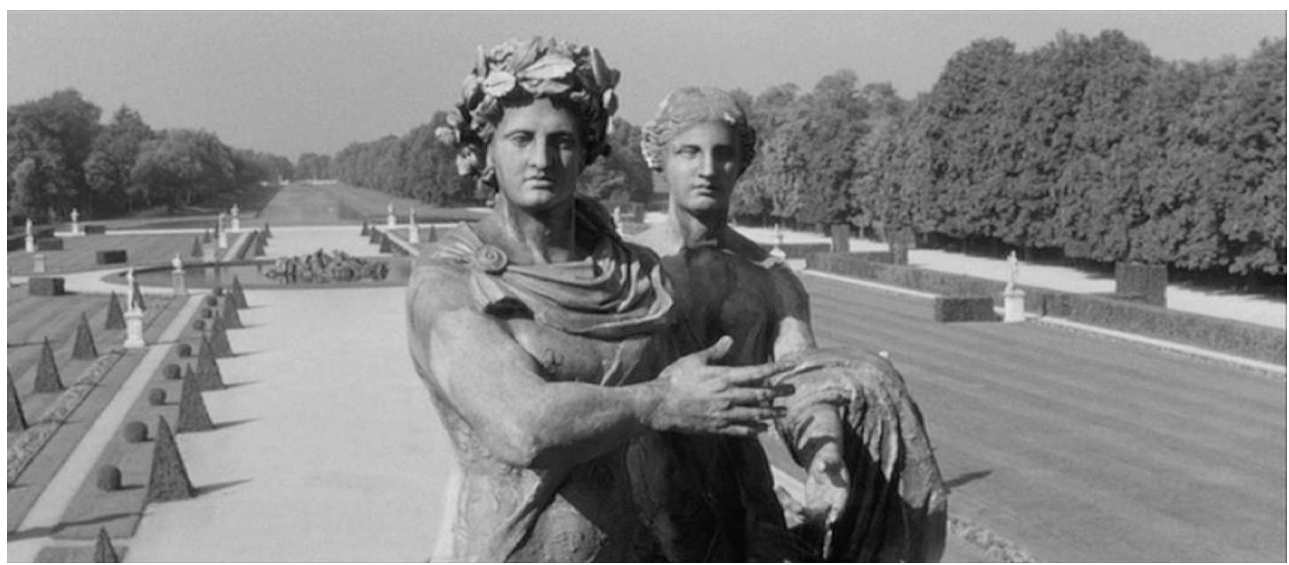

Fig. 13: Alain Resnais, L'Année dernière à Marienbad (1961)

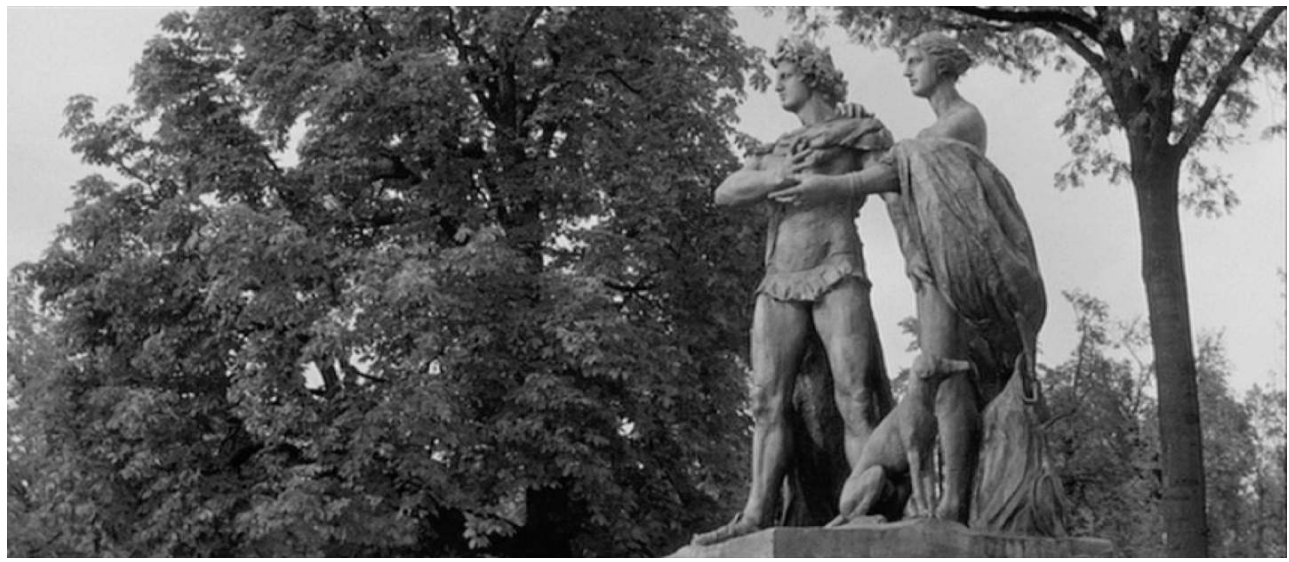

Fig. 14: Alain Resnais, L'Année dernière à Marienbad (1961) 


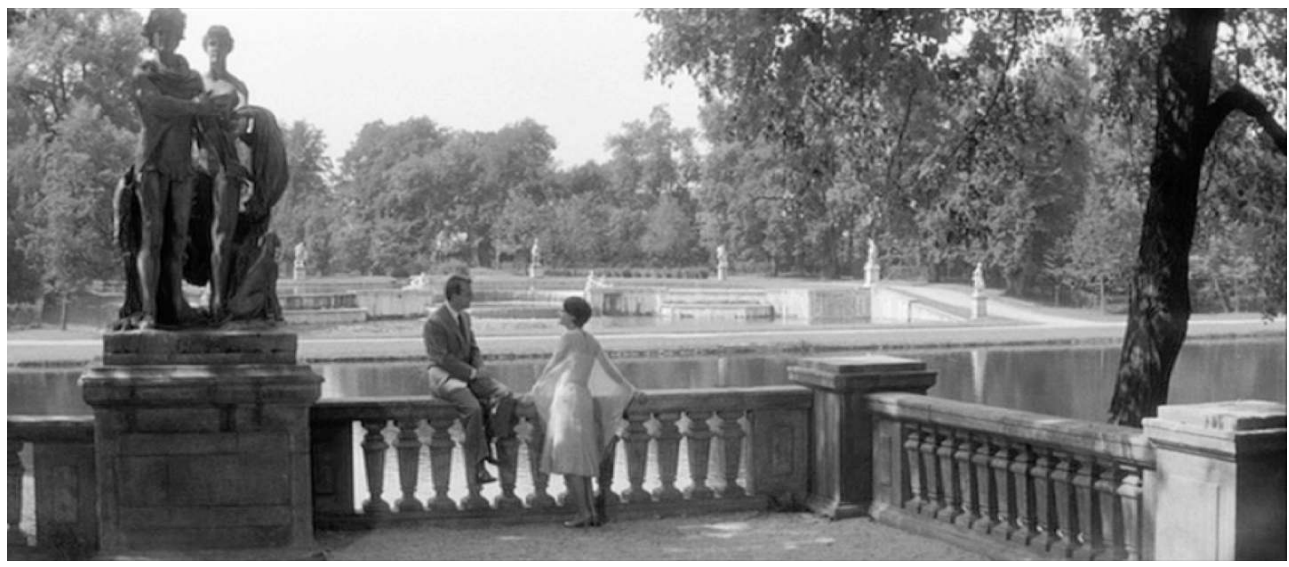

Fig. 15: Alain Resnais, L'Année dernière à Marienbad (1961)

16 As with the sculpture in outdoor settings in Marienbad, Resnais used actor movements (blocking), camera movements, and optical reflections to challenge the conventional filmic construction of interior space. For example, in a single shot, almost two minutes long, early in the film, those devices complicate perception of what is, in fact, a simple succession of rooms en suite. At the opening of the shot, $\mathrm{X}$ appears at the left, near a wall, while an arguing couple is reflected in a mirror to the right (fig. 16). The reflection also shows that the three figures occupy a large room, through one portal of which other hotel guests are visible. The camera pans right until the couple appears in the center of the image. The two then walk towards the reflection, eventually passing in front of the camera, which pans left to follow them (fig. 17). As the couple walks away from the camera into an adjacent room, they pass two men walking in the opposite direction-that is to say, toward the camera (fig. 18). The camera begins tracking backward in a straight line so as to maintain a steady distance from the advancing men, eventually entering a room behind, in line with those already seen. The camera pans left to follow the men, but it holds on two other men already standing there: $\mathrm{X}$ and an older man, who stares at the engraved image of the garden mentioned above (fig. 19). $X$ then walks back towards the right, with the camera following his movement. As he nears the doorway leading back to the room just abandoned, one sees along the wall to the right, inside the new room, the same arguing couple seen earlier in mirror reflection and then walking away from the camera (fig. 20). Given that previous departure and the planimetric clarity of the camera's own tracking movements, the position of the couple seems unexpected, if not impossible, and therefore casts doubt on the coherence of the architectural space.

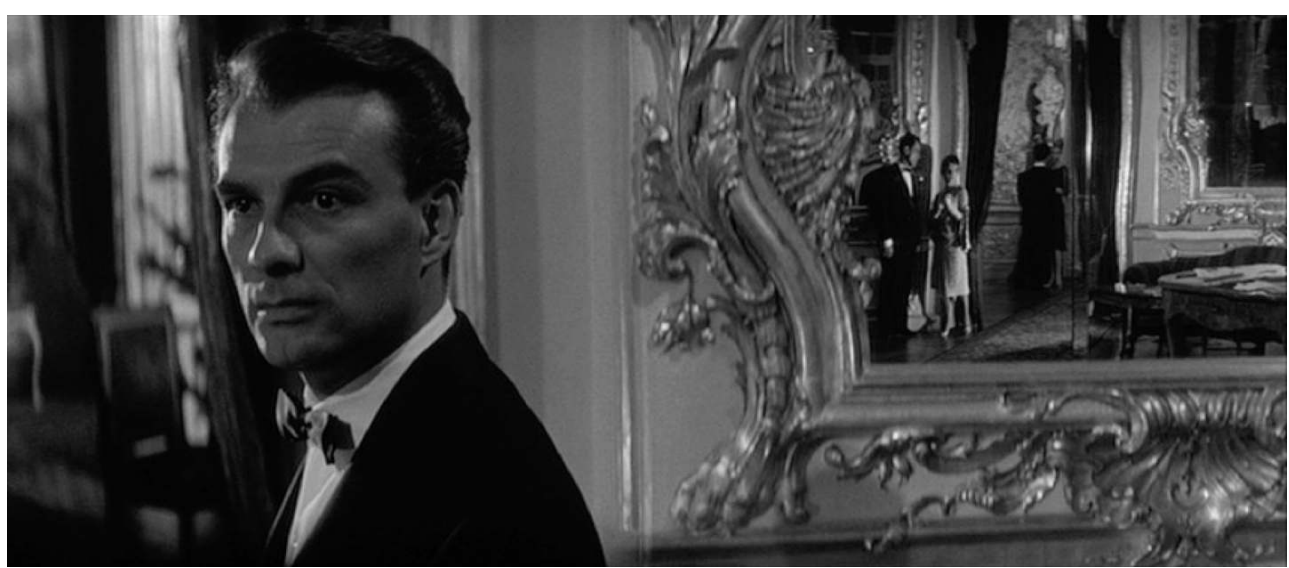

Fig. 16: Alain Resnais, L'Année dernière à Marienbad (1961) 


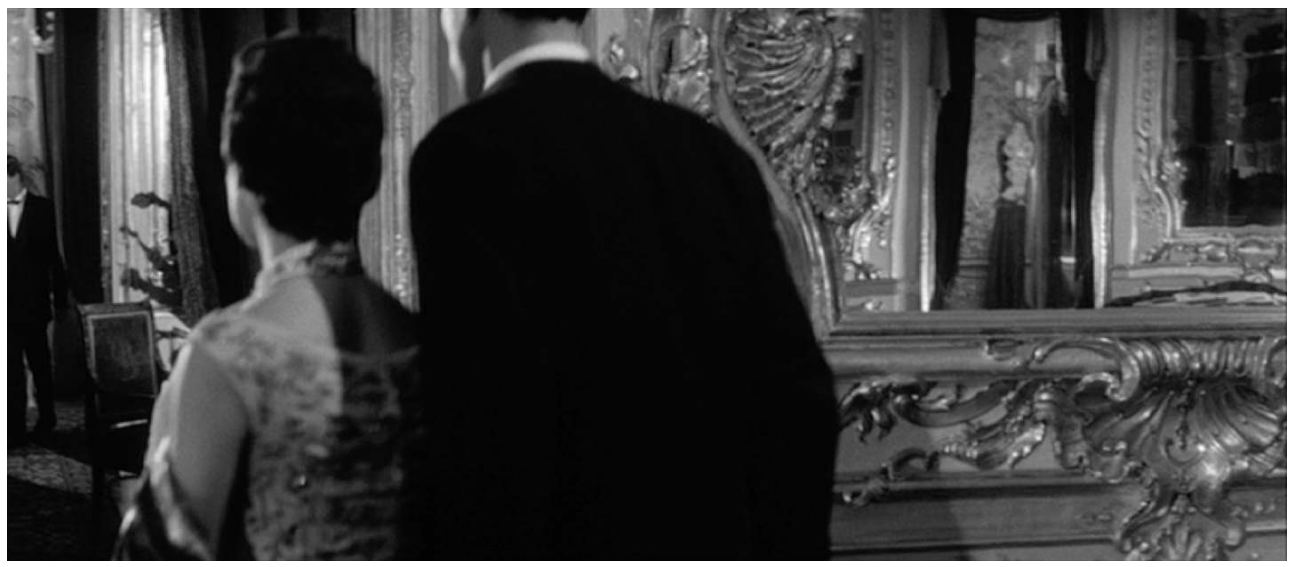

Fig. 17: Alain Resnais, L'Année dernière à Marienbad (1961)

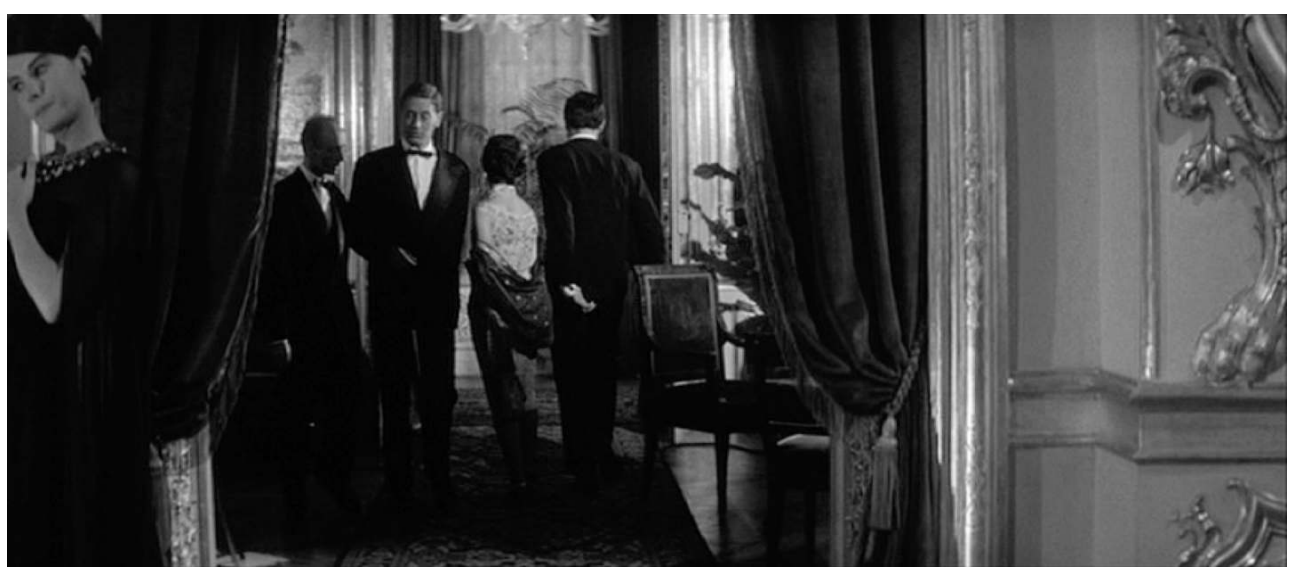

Fig. 18: Alain Resnais, L'Année dernière à Marienbad (1961)

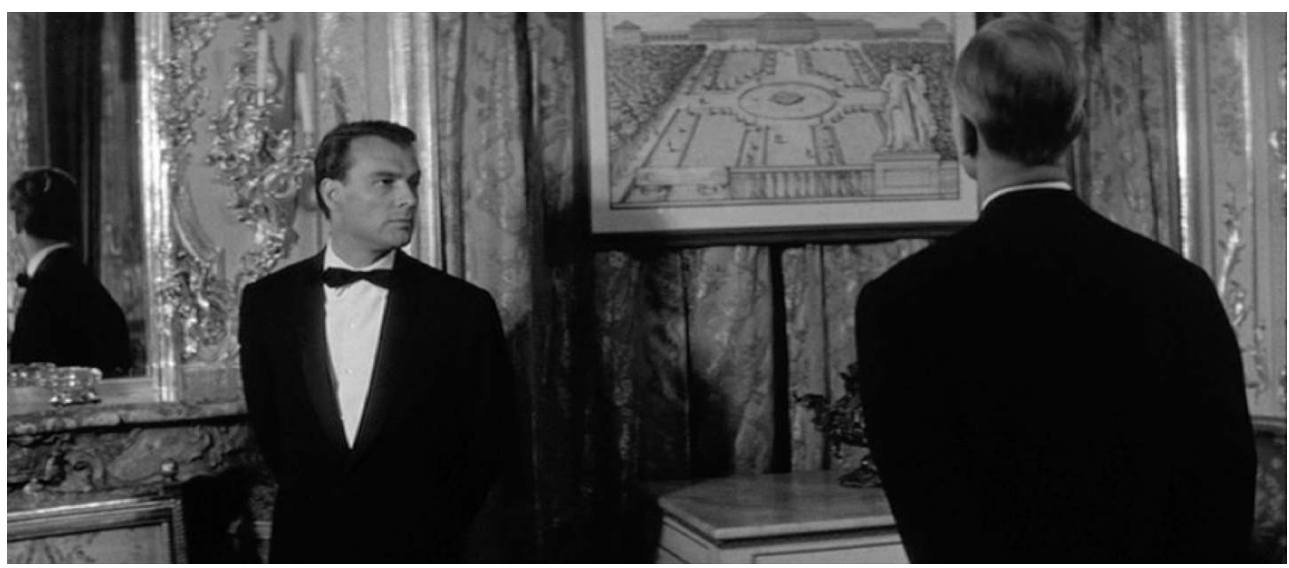

Fig. 19: Alain Resnais, L'Année dernière à Marienbad (1961) 


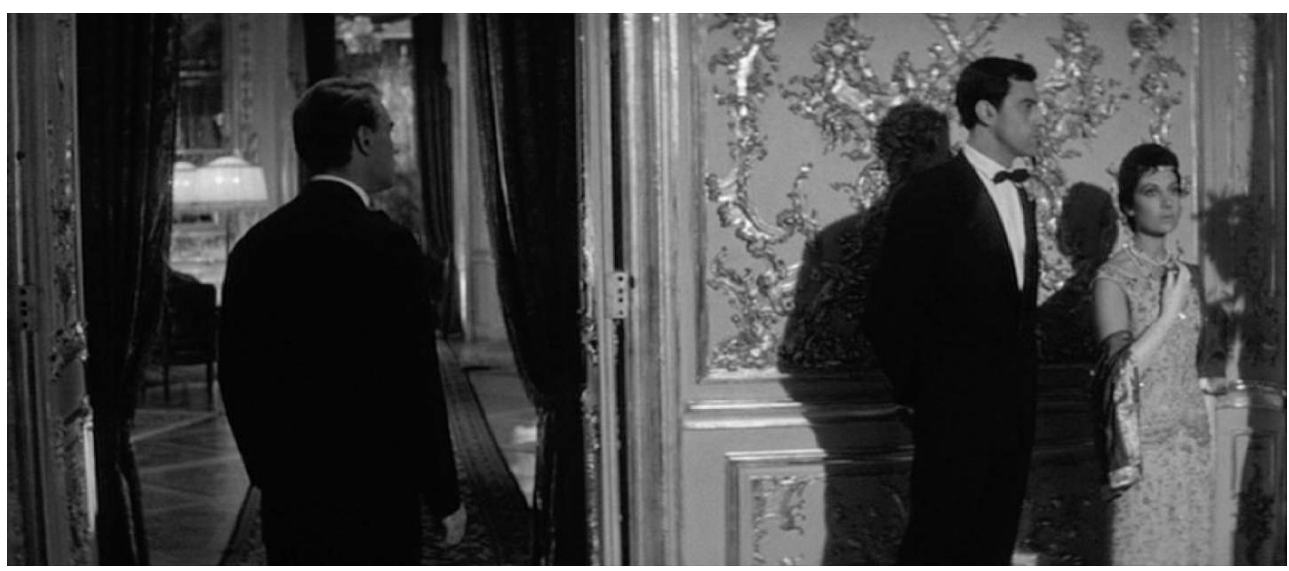

Fig. 20: Alain Resnais, L'Année dernière à Marienbad (1961)

17 Resnais's way of subverting filmic space in Marienbad drew on his background as a film editor and was influenced by the "anti-Cartesian" writings of filmmaker and theorist Jean Epstein (1897-1953). ${ }^{22}$ Epstein's essay "Le cinéma et les au-delà de Descartes" (1946) asserted that the invention and development of the movie camera was connected to a recent, historic shift away from Cartesian traditions in mathematics, science, and philosophy (22). From the time of its formulation in the seventeenth century, Cartesian method had vast shaping influence on Western culture, building on core concepts such as the dualist nature of the universe-its division into "thinking substance" (mind) and "extended substance" (matter)-and the certainty of analytic geometry, with its methodical use of coordinate systems. However, given the revolutions in mathematical and scientific thought during the late-nineteenth and early-twentieth centuries, and in the wake of two World Wars, those positions no longer made sense. Epstein argued that, through its own "propagande discrète", the movie camera could cast doubt over outmoded accounts of space and time, thereby liberating viewers from the tenacious legacy of Cartesian thought and extending to modern society changes equivalent in magnitude to those already achieved in science. Epstein regarded camera movement and editing as "la meilleure expérience préparatoire à la critique de toutes les notions traditionnelles qui se prétendaient absolues, à la formation de cette mentalité relativiste qui, aujourd'hui, pénètre généralement les connaissances" (22).

Epstein's ideas resonated strongly with Resnais, who had begun his career in cinema as a film editor. ${ }^{23}$ As Resnais transitioned into directing, editing remained a priority in his approach, and he drew inspiration from Karel Reisz's widely disseminated textbook, The Technique of Film Editing ( $1^{\text {st }}$ published 1953, with many later editions) - so much so, in fact, that he called Reisz his "real teacher" (Monaco 40). ${ }^{24}$ In his book, Reisz explained in a systematic way how film editing could be used to cultivate viewer interest while constructing "a lucid continuity" (Reisz 216-227). While he insisted that the primary role of editing was to support dramatic action $(227),{ }^{25}$ his main chapter on praxis concluded in a highly evocative way by invoking a "pure cinema" constituted through editing alone:

In the examples we have chosen, [...] the selection of shots was largely designed to reinforce the effectiveness of the dialogue and the acting.

It now remains for us to look at some less typical examples in which the actual choice of images is the crucial creative process. In these, the very acts of selecting the shots and their subsequent juxtaposition are designed to convey emotions and ideas which are not capable of any other form of expression. We are, in fact, dealing with passages of pure cinema in which the editing pattern is the film. (249) ${ }^{26}$ 
With a mind to dramatic action, Reisz asserted that "[e]very cut [...] should make a point. There must be a reason for transferring the spectator's attention from one image to another" (220). But with an eye to transforming cinema, Resnais used cuts in Marienbad to further his exploration of representation, history, and the human body. Throughout the film, forms of the body are graphically matched across cuts in which other visual elements change, a technique not described by Reisz but tested by Resnais in the flashback sequence in Hiroshima. Multiplied in that way, the body develops a reputation for stability and coherence usually reserved for filmic space but here denied to it.

For example, in several scenes in Marienbad, the position and dress of a figure are maintained across a cut while the setting changes radically. The first example of that effect occurs early in the film, in the sequence in which audience members socialize in the theater following the stage performance. Among them is a blond woman in a lacetrimmed cocktail dress, who appears standing to the left of a man with a moustache (fig. 21). Several shots later, the two appear again in the same clothing and relative positions, but in a different space, the hotel lobby, and they seem to chat with someone off-screen (fig. 22). Two shots follow in which women are seen staring off-screen, as if lost in thought or mesmerized by someone or something not visible within the frame. ${ }^{27}$ In the next shot, the first blonde appears again, now standing alone in the back of the theater and staring off-screen like the women in the preceding shots (fig. 23). After a marked pause, she begins to turn around (fig. 24). Part way through her turn, the setting around her changes completely, from the theater to the hotel lobby (fig. 25), seen from a new angle. The cut was carefully edited so that the movement of the woman appears continuous. She looks about the lobby, as if suddenly awakened to her environment, then completes her turn (fig. 26).

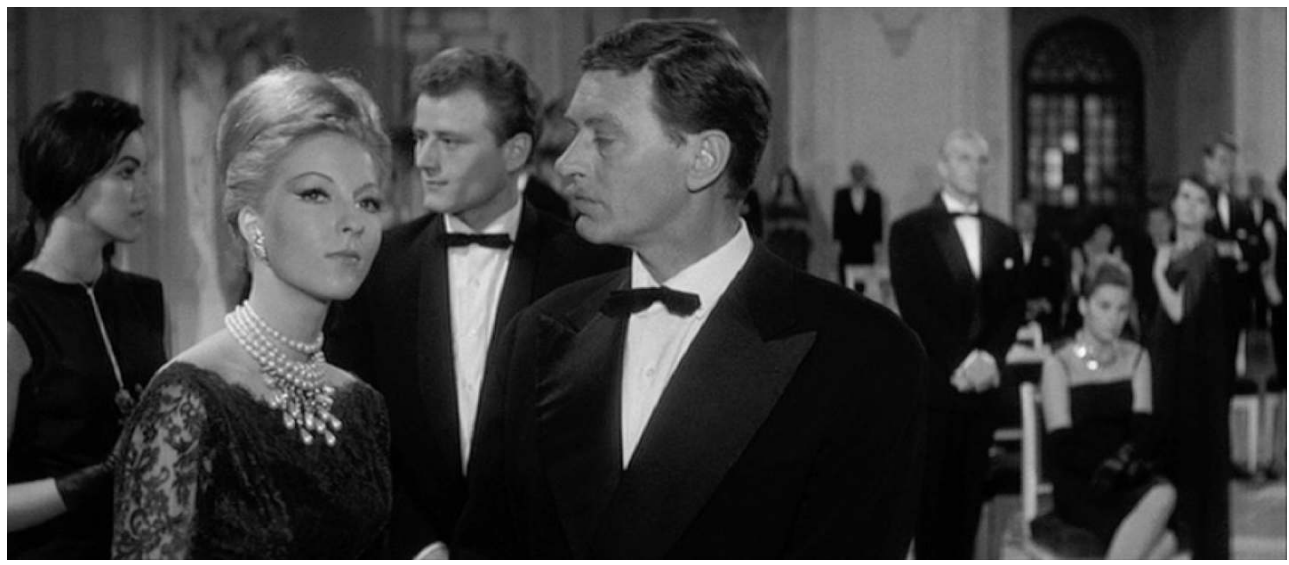

Fig. 21: Alain Resnais, L'Année dernière à Marienbad (1961) 


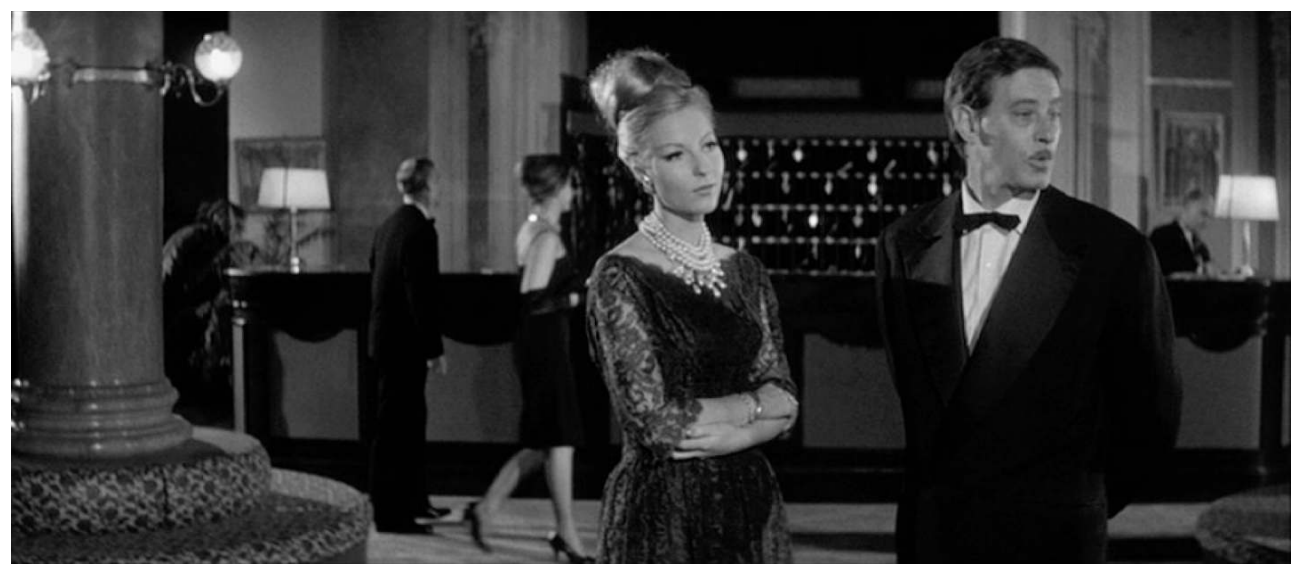

Fig. 22: Alain Resnais, L'Année dernière à Marienbad (1961)

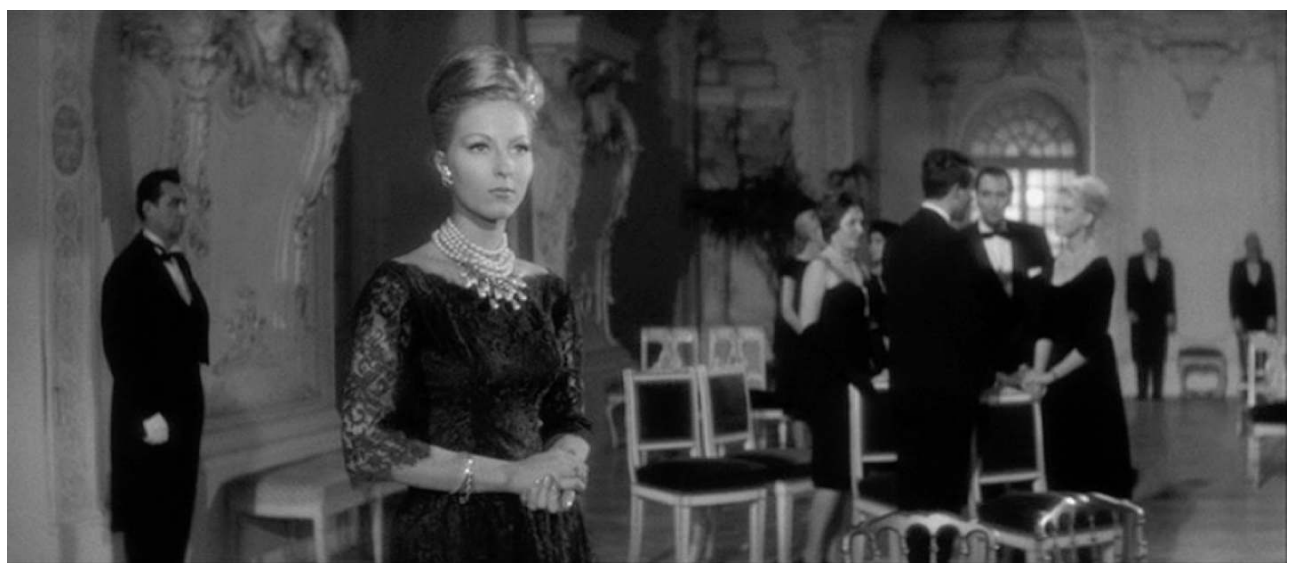

Fig. 23: Alain Resnais, L'Année dernière à Marienbad (1961)

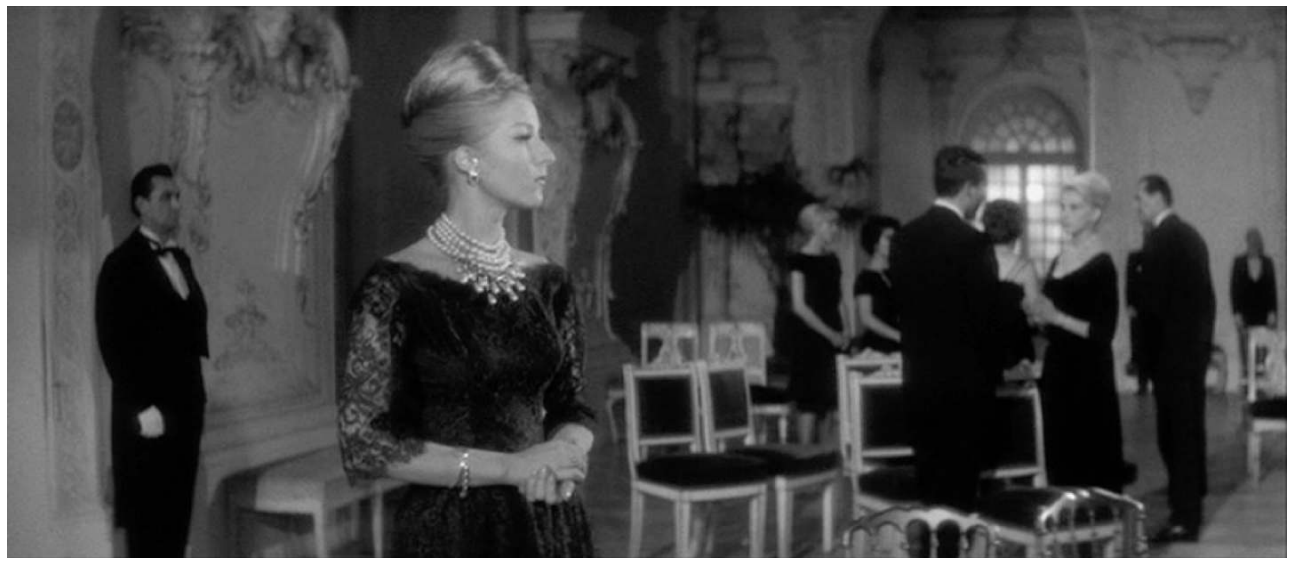

Fig. 24: Alain Resnais, L'Année dernière à Marienbad (1961) 


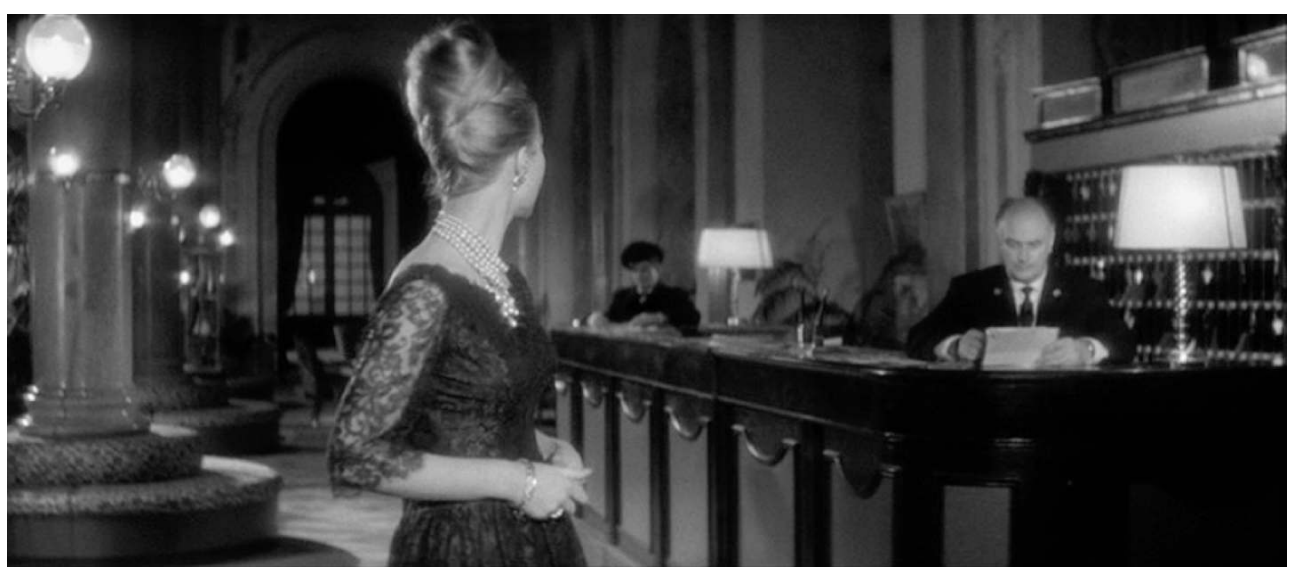

Fig. 25: Alain Resnais, L'Année dernière à Marienbad (1961)

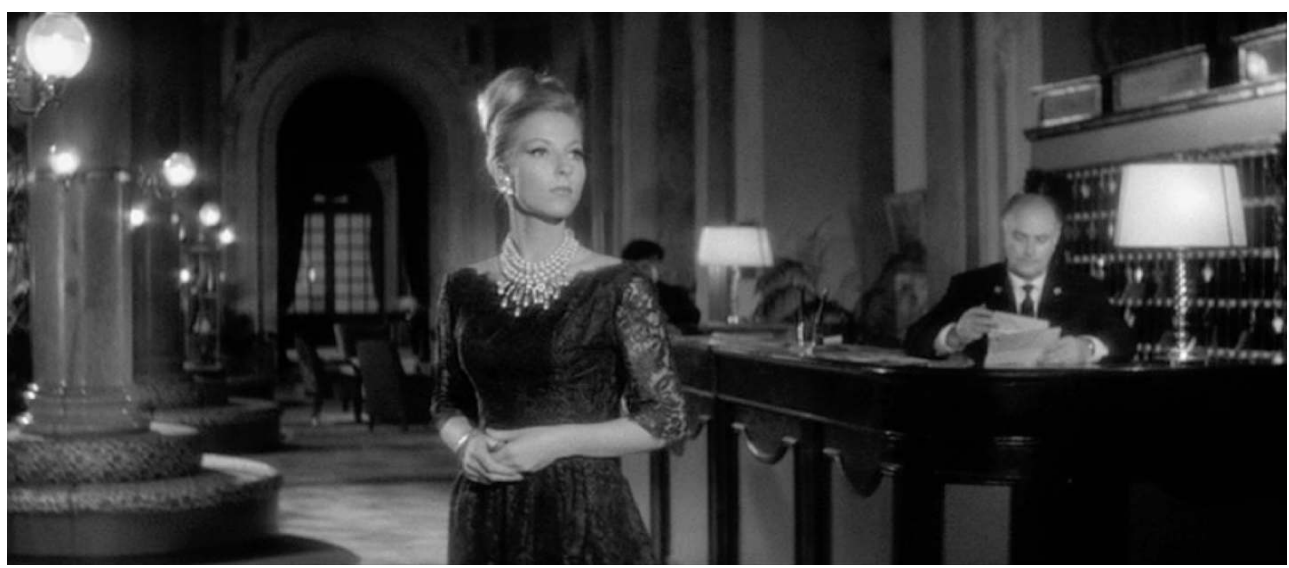

Fig. 26: Alain Resnais, L'Année dernière à Marienbad (1961)

21 Another example of this effect occurs about two-thirds of the way into the film. X and A walk together down a long, elaborately decorated corridor. They stop, and X shows A the photograph of her that he claims is proof of their earlier liaison (see fig. 1). They continue to walk, and they stop once more. A then crosses in front of $\mathrm{X}$, and, just as her body passes in front of his, the setting changes completely (fig. 27 and 28). What had been a hallway is now a large room. Several yards behind the couple, one sees the portal of a much plainer hallway than the one passed through a moment before. The length of the 
shot also changes slightly, from three-quarters to full-length, but the positions and postures of the figures within the frame are preserved.

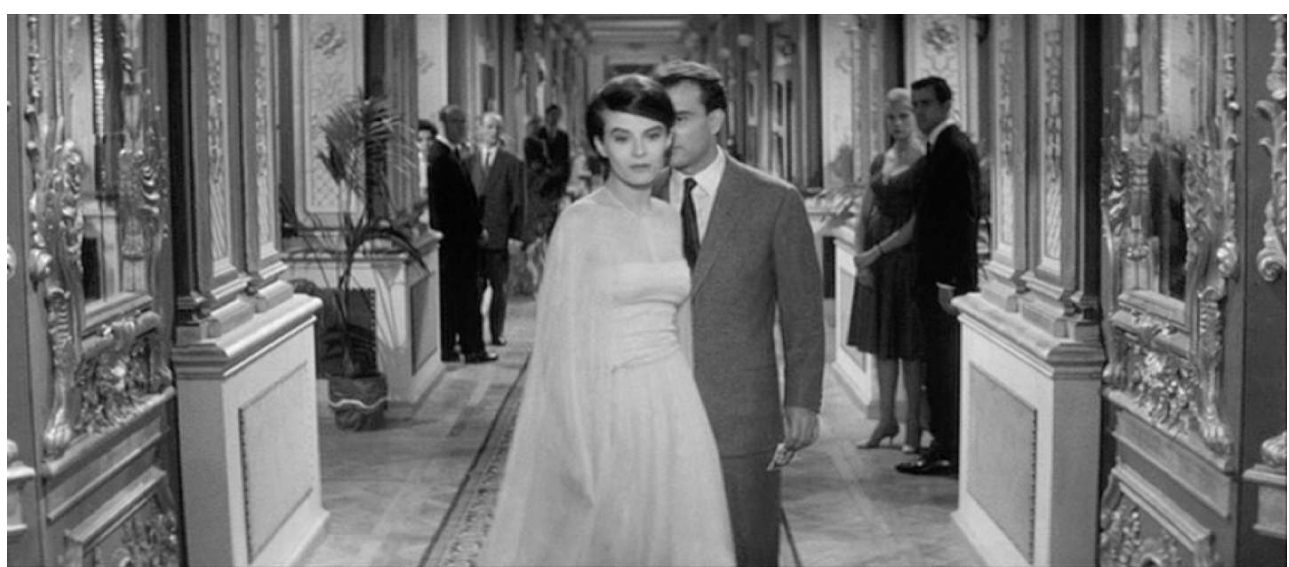

Fig. 27: Alain Resnais, L'Année dernière à Marienbad (1961)

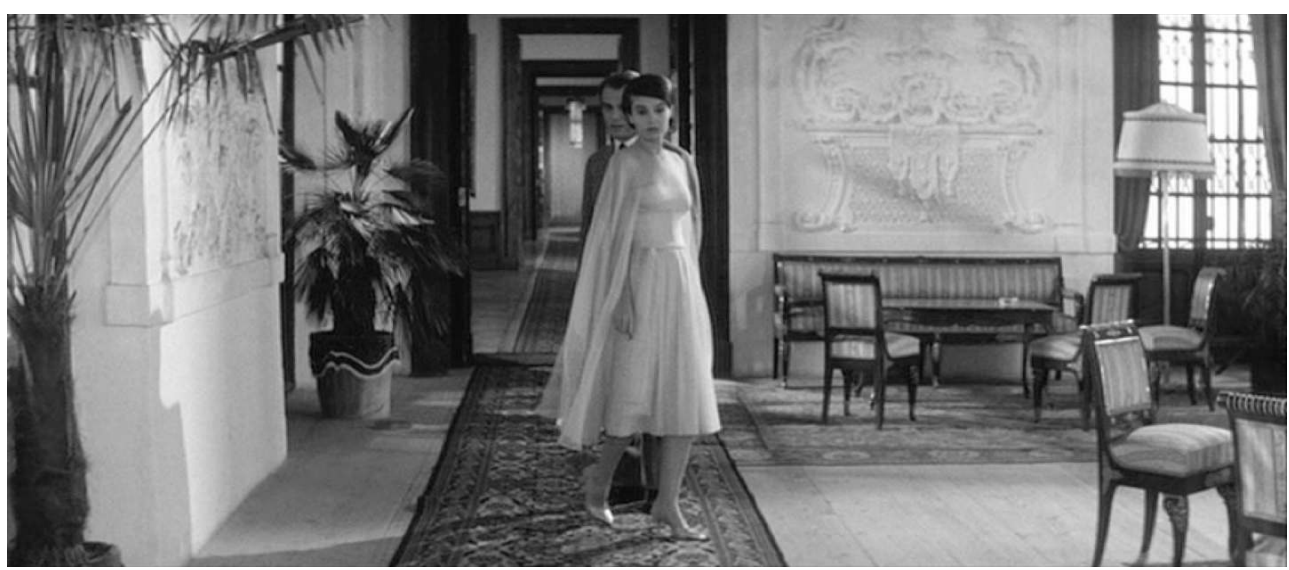

Fig. 28: Alain Resnais, L'Année dernière à Marienbad (1961)

In a variation on this practice of graphic matching, the position of a figure is maintained while both setting and dress suddenly change. For example, about ten minutes before the end of the film, X and A stand together in the moonlit garden. Hearing the approach of footsteps, A begs X to flee. He climbs over a balustrade, which then collapses. A screams, and, as she does so, the setting changes suddenly to the bar in the hotel ballroom (fig. 29 and 30). A's clothing also changes, but her posture, expression, and position within the frame are preserved. Those also match an earlier scene in the film, here reintroduced, in which A, suddenly terrified, screams near the bar and drops her glass. 


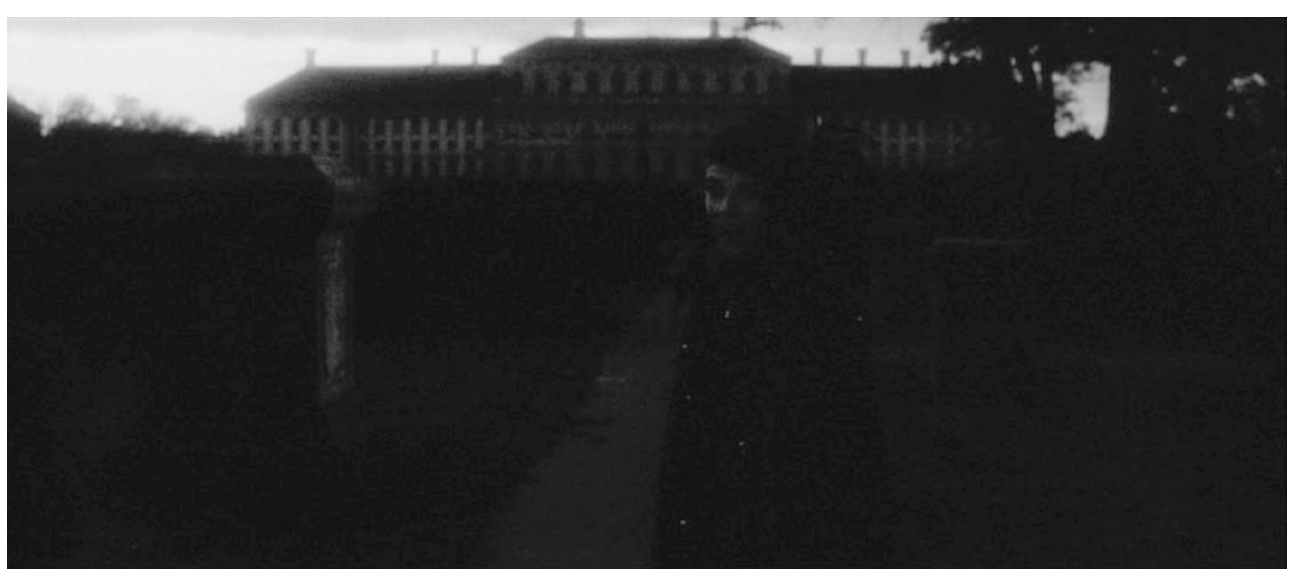

Fig. 29: Alain Resnais, L'Année dernière à Marienbad (1961)

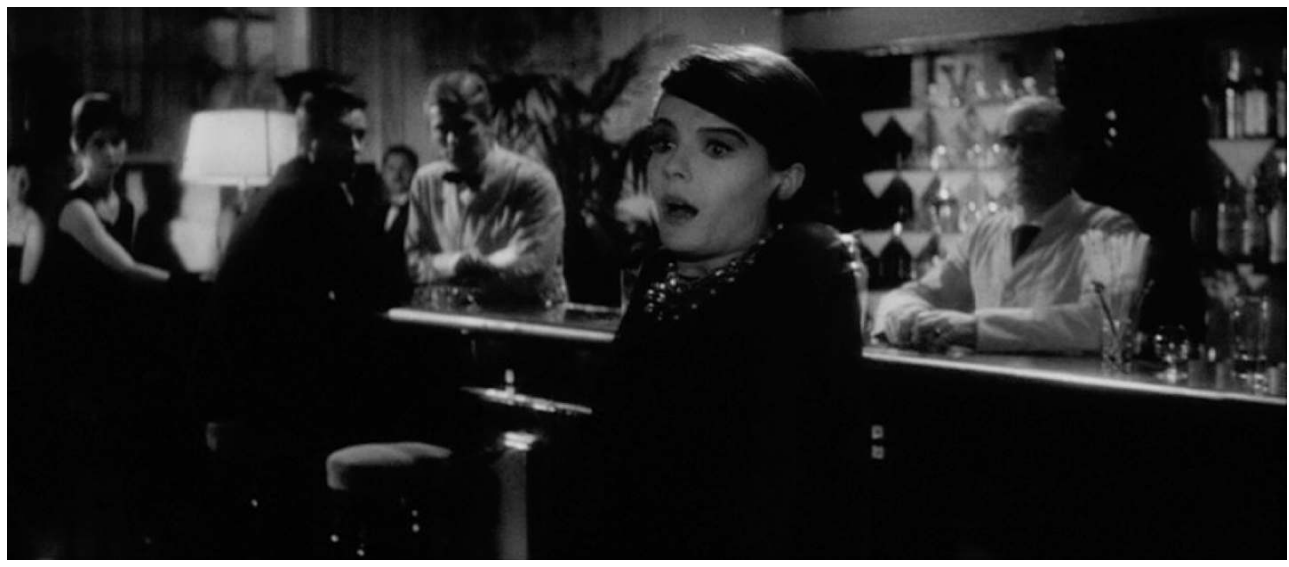

Fig. 30: Alain Resnais, L'Année dernière à Marienbad (1961)

23 Lastly, in another variation of graphic matching, body positions are maintained across cuts, but the figures themselves change, as do their settings. A string of examples occurs during the stage performance at the beginning of the film. Part way through, $\mathrm{M}$ stands alone at the back of the audience. The camera moves left and back, away from him, until he is seen in three-quarter-length near the right edge of the frame (fig. 31). The shot then cuts to the stage, and the figure of $\mathrm{M}$ is replaced by that of the actress, also three-quarter length and holding the same position within the frame (fig. 32). Four shots later, the effect is repeated using the same two figures, with M's shape matched by that of the actress and the camera moving right and forward, closer to him, rather than away. The sort of matching seen between $\mathrm{M}$ and the actress also takes place between groups of figures. Following the stage performance, three audience members climb a grand staircase and stop halfway up to chat (fig. 33). A woman with black hair stands on the left, with her back to the camera, while a bald man in the center faces the camera, and a man on the right faces the woman. The image then cuts to three different figures in a very different setting-a hall, or the corner of a room, seen in mirror reflection-but holding roughly the same positions within the visual field (fig. 34): the blonde referenced earlier (in the lace-trimmed cocktail dress) on the left with her back to the camera, a man in the center facing the camera, and a man on the right facing the woman. 


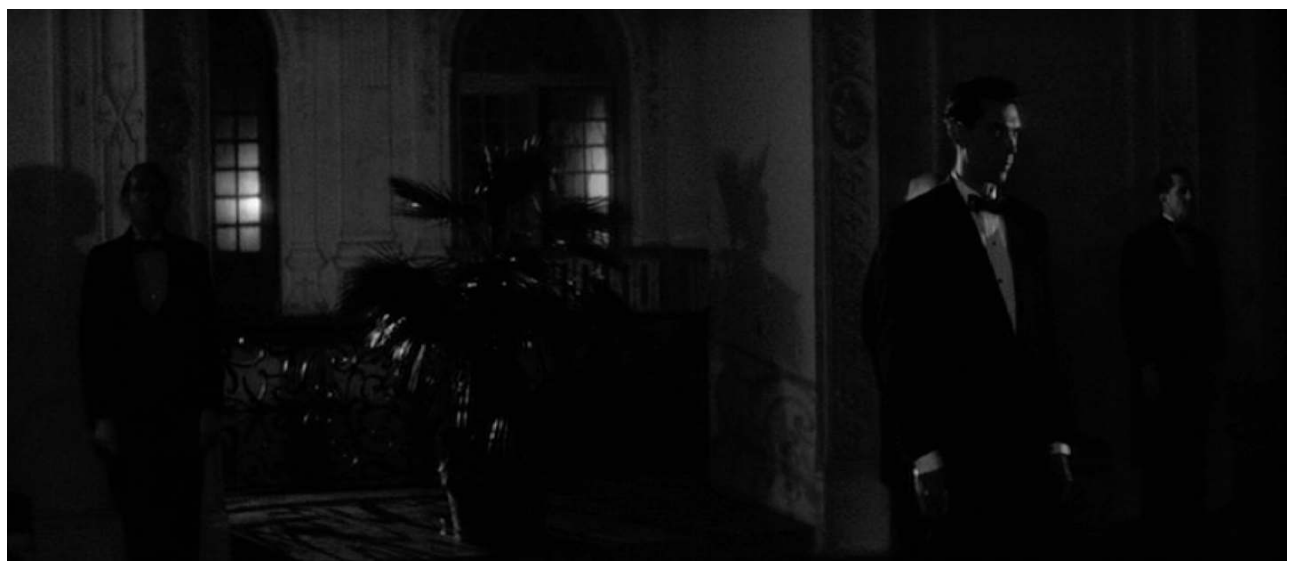

Fig. 31: Alain Resnais, L'Année dernière à Marienbad (1961)

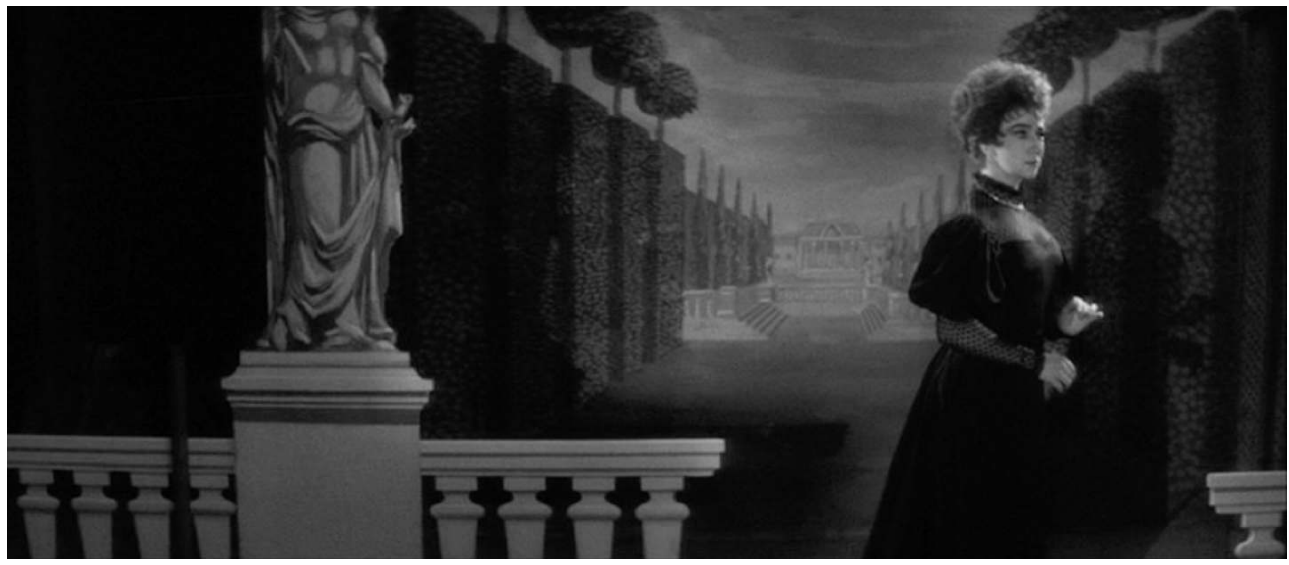

Fig. 32: Alain Resnais, L'Année dernière à Marienbad (1961)

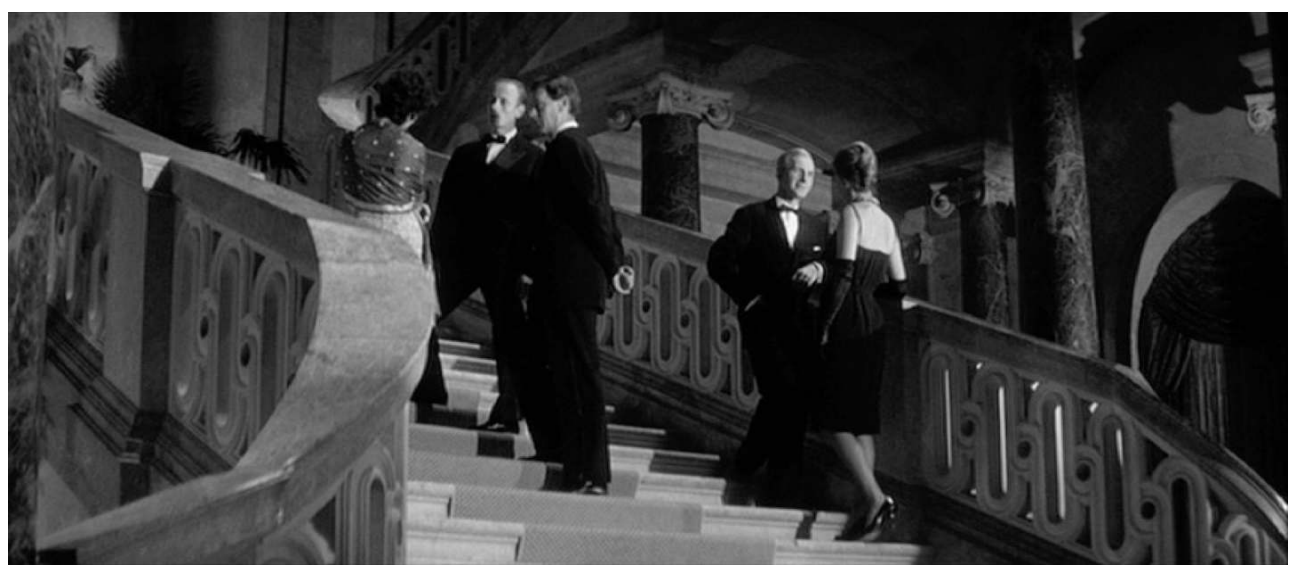

Fig. 33: Alain Resnais, L'Année dernière à Marienbad (1961) 


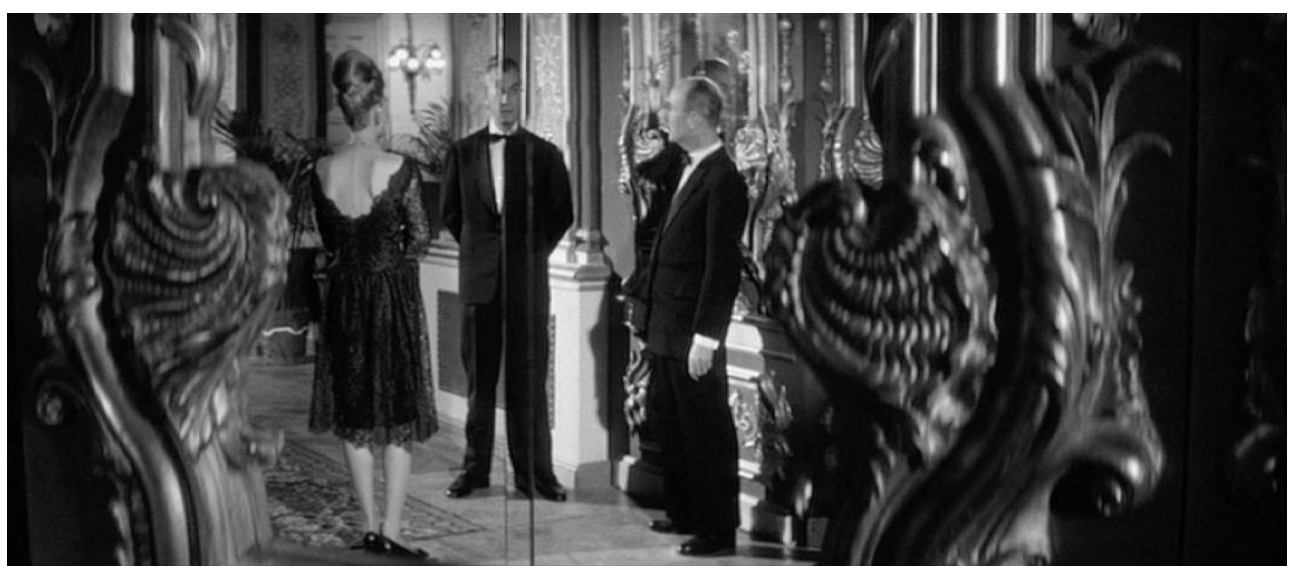

Fig. 34: Alain Resnais, L'Année dernière à Marienbad (1961)

Over and over in Marienbad, the human body is presented as stable and continuous within the volatile visual field of the screen. Graphic matches across cuts train viewers to see the body as a site of coherence and orientation, qualities traditionally associated with the classical "unity of place", on which the credibility of dramatic action was long thought to depend, but here cultivated at the expense of that priority. In other words, images of the transcendent body are at once grounding and destabilizing in Marienbad, invoking the multiple, symbolically central scenes in which A confronts a photograph of herself. The photograph traumatizes A by embodying her condition of knowing and not knowing. Rooted in indexicality, yet easily reproduced (as demonstrated when A finds many copies in a desk drawer), it allows the past to become active and blurs the distinction between memory and perception-thereby foreclosing A's ability to "pass beyond [her]self". ${ }^{28}$ In a similar way, graphic matching across cuts haunts Marienbad by embodying its condition of moving and not moving-a paradox not lost on Resnais, given his basis in editing. Rooted in still images, yet virtually continuous, such matching allows the past to become active and blurs the distinction between memory and perception-thereby foreclosing the ability of the film to "pass beyond [it]self". ${ }^{29}$

In Marienbad, the terms of that paradox are made explicit in various stagings of the time freeze effect. For example, in the five-shot sequence of audience members socializing following the theatrical performance, figures transition from moving to not moving in the first shot, then from not moving to moving in the second, and so on through the sequence, as if repeatedly crossing a margin-at once historical and technical-between photography and film. In fact, the "stills" in Marienbad are not freeze frames, in which a photographic image is extended through repetition; rather, they are time freeze effects, in which performers hold their positions, like statues or as if frozen. ${ }^{30}$ Signs of life can be glimpsed in subtle movements-a blink, a sway, the sparkle of a gem, a chest moving with breath-just as, in Hiroshima, the lovers' fingers twitch. Yet, those movements remain rooted in stillness-an endless collapsing of the virtual into the actual.

Later in Marienbad, the camera glides among motionless guests in large, dimly-lit, public areas of the hotel (fig. 35). In another scene, A walks among guests standing around the lobby, all of them motionless except $\mathrm{M}$, who watches her and turns his head and upper body while following her movement (fig. 36 and 37). In these scenes, moving and not moving are "distinct, but indiscernible" aspects of the paradox of filmic time. In his twovolume treatment of cinema, movement, and time, philosopher Gilles Deleuze described a historical transition from the "movement-image" of classical cinema, in which time is a 
function of "traditional sensory-motor situations", to the "direct time-image", manifest in "purely optical and sound situation[s]" (Deleuze 12, 18). As an epitome of the latter, he pointed to the vase scene in Yasujiro Ozu's film Late Spring (1949), in which time is manifest not in story or bodily movement but in the persistence of form inside of which change nevertheless occurs:

The vase in Late Spring is interposed between the daughter's half smile and the beginning of her tears. There is becoming, change, passage. But the form of what changes does not itself change, does not pass on. This is time, time itself, "a little time in its pure state": a direct time-image, which gives what changes the unchanging form in which the change is produced. [...] Ozu's still lifes endure, have a duration, over ten seconds of the vase: this duration of the vase is precisely the representation of that which endures, through the succession of changing states. (17)

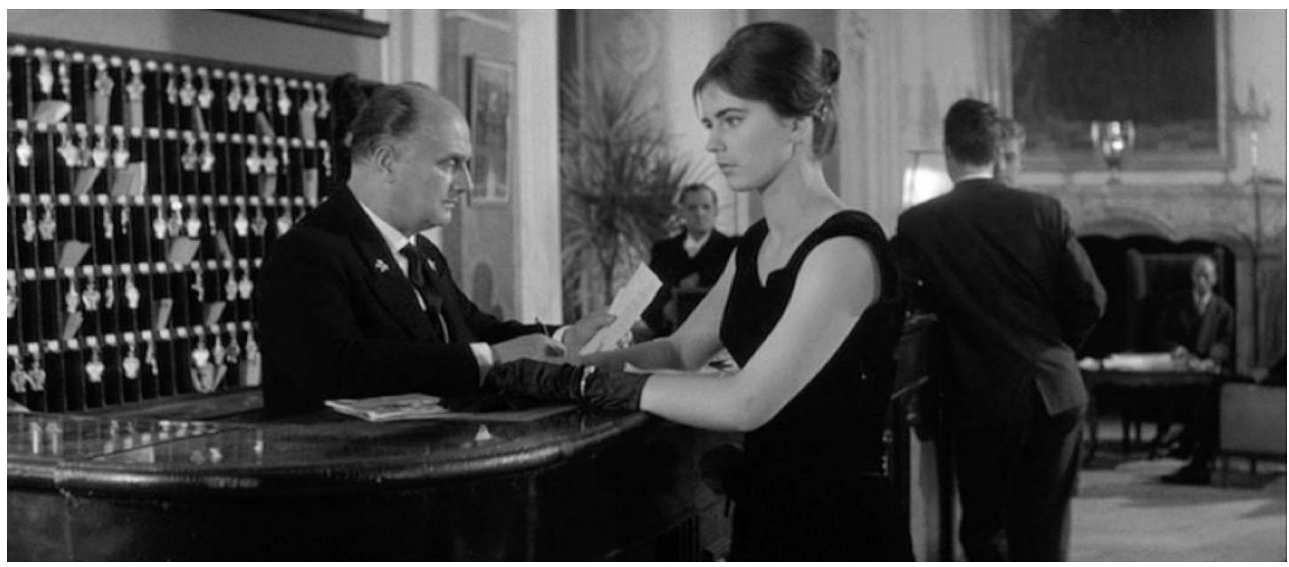

Fig. 35: Alain Resnais, L'Année dernière à Marienbad (1961)

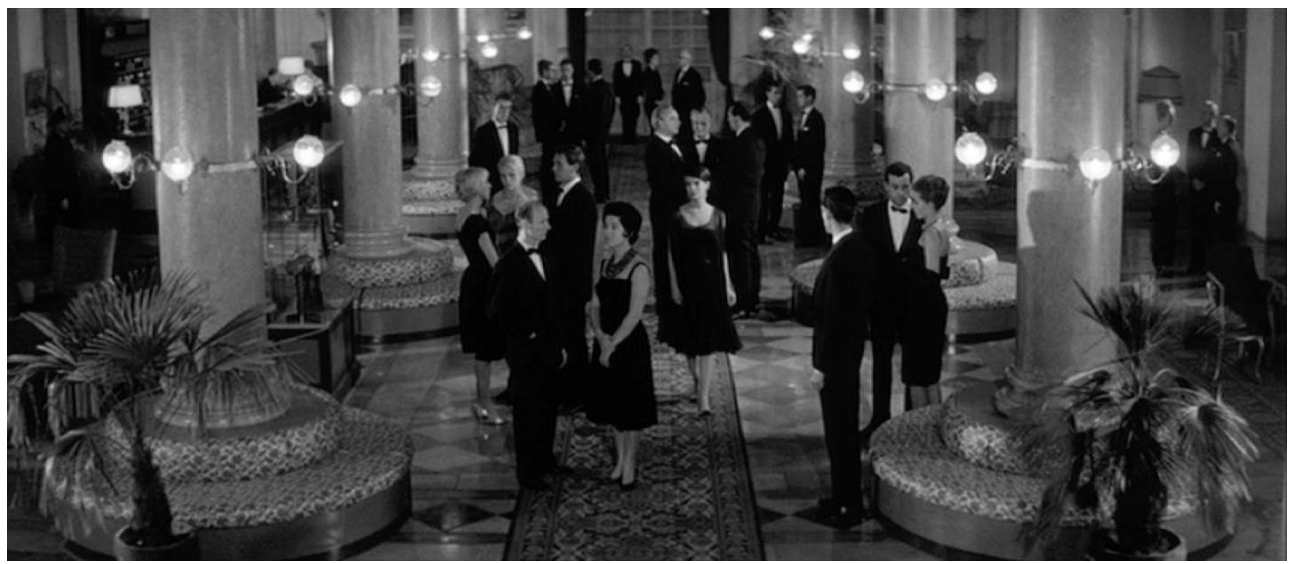

Fig. 36: Alain Resnais, L'Année dernière à Marienbad (1961) 


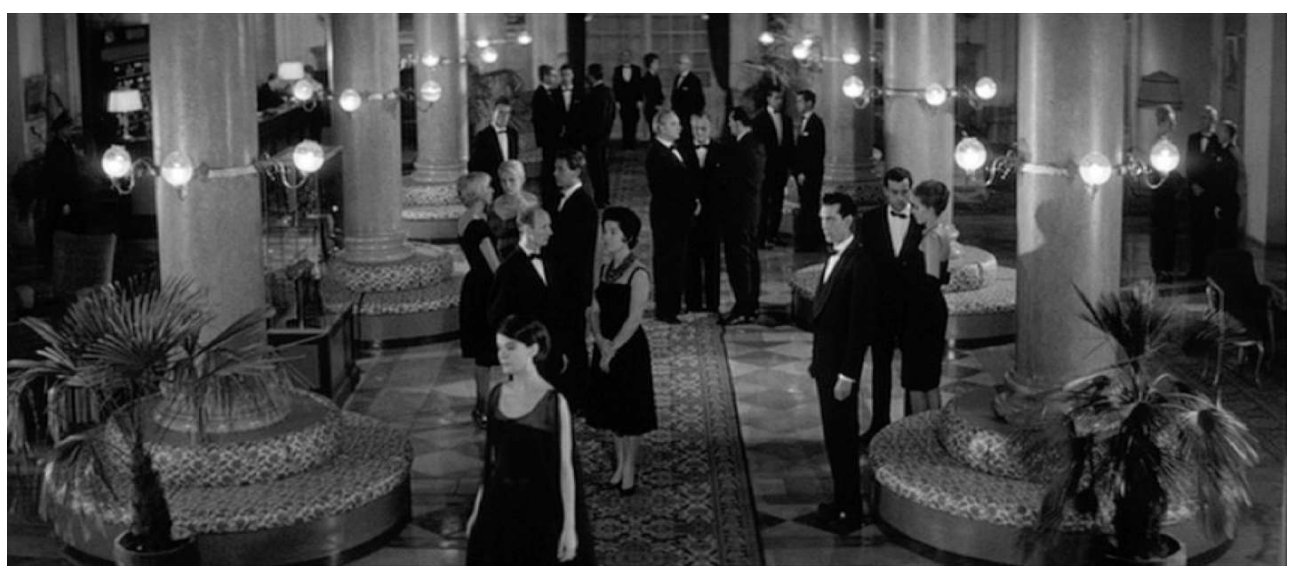

Fig. 37: Alain Resnais, L'Année dernière à Marienbad (1961)

27 As a "still life" with duration, in which moving and not moving are "distinct, but indiscernible", the vase scene in Late Spring relates to many moments in Marienbad, but most powerfully to the iconic scene near its midpoint-a single shot lasting twenty-two seconds-during which the camera moves past a balustrade to reveal nine figures standing in the "empty" central axis of a French-style garden (fig. 38). The figures appear motionless, like the statues surrounding them. Reinforcing the film's lessons about the integrity of the human body and the dubiety of traditional (Cartesian) space, the figures cast long shadows while the forms of the setting cast none. Fifteen seconds into the shot, the camera halts, and the scene seems completely still, as if transformed into a photograph. ${ }^{31}$ However, as with the other "stills" in Marienbad, this is a time freeze shot, not a freeze frame; while the figures hold their positions, wind gently flutters the skirts of several women.

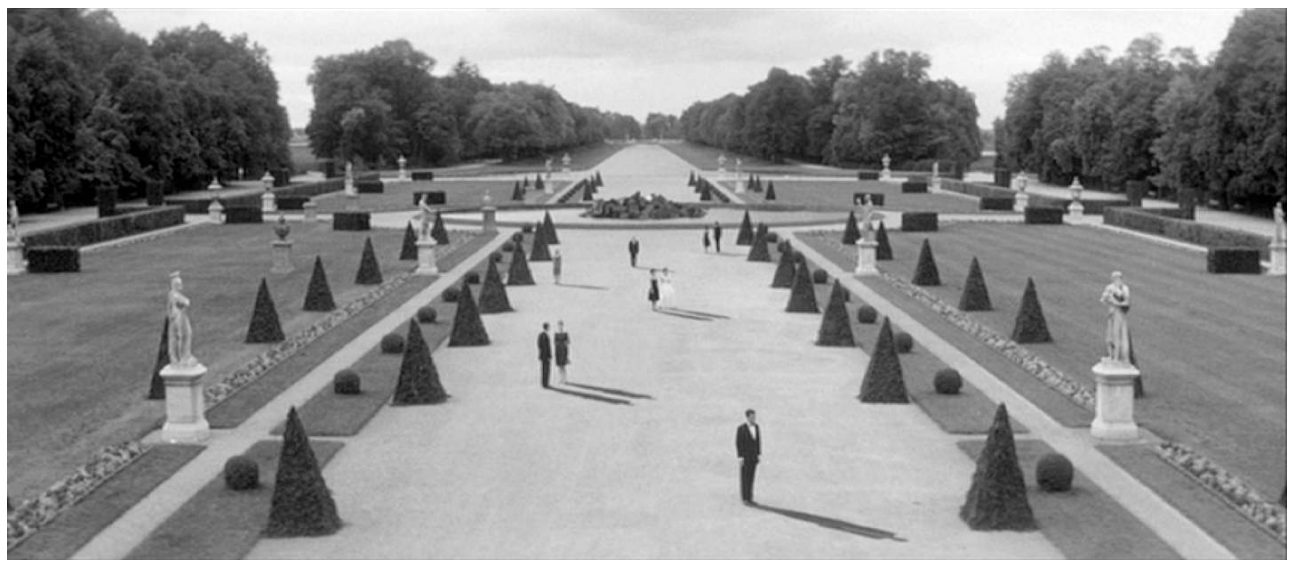

Fig. 38: Alain Resnais, L'Année dernière à Marienbad (1961)

As a "still life" with duration, this pivotal scene in Marienbad is a "direct time-image" in the sense defined by Deleuze. But its resonance with Ozu's Late Spring goes beyond the vase scene to the one immediately following it: a sequence of eight shots set in the meditation garden at Ryoan-ji, an important Zen temple in Kyoto, Japan. During that scene, two men sit and talk on the veranda overlooking the garden. In their moving and not moving-their "unchanging form in which the change is produced"-they are related visually to the distinctive rock clusters there. ${ }^{32}$ In the garden scene in Marienbad, the nine figures are compared to the same rock clusters, but in a different way: specifically, they stand in the pattern of their layout at Ryoan-ji (fig. 39). Although highly suggestive, that 
reference is easily overlooked; to my knowledge, it has not been noticed or remarked upon before now, at least in publication. The success of Late Spring had recently made the garden at Ryoan-ji famous, ${ }^{33}$ and Resnais would have known it because of that film, if not in another way. But Ozu did not show the garden as a whole, whereas Resnais displayed its general configuration-provocatively, with one additional "rock" cluster, embodied by a "gray" figure, at the far left.

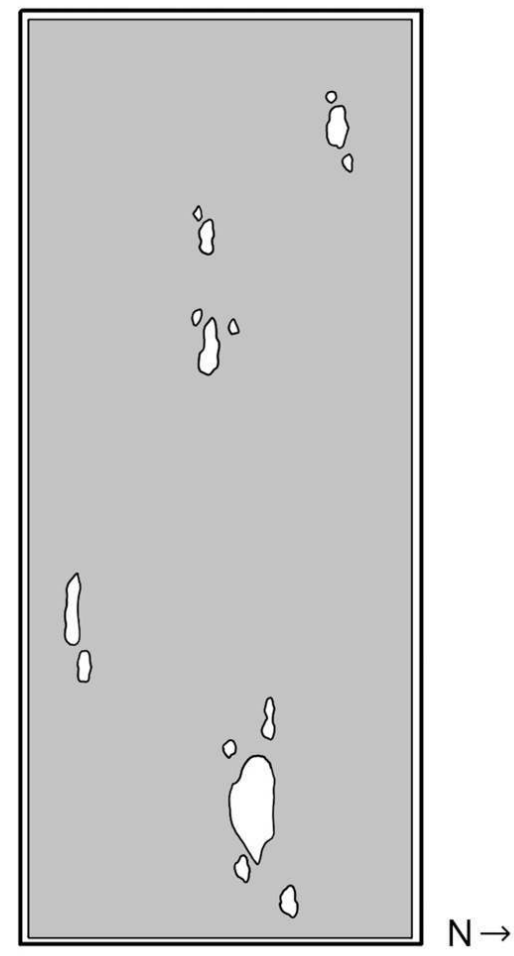

FIg. 39: POSITIONS OF ROCK CLUSTERS IN THE ZEN MEDITATION GARDEN AT RYOAN-JI (15TH-CENTURY, KYOTO, JAPAN). DRAWING BY THE AUTHOR AFTER GEOFFREY AND SUSAN JELLICOE, THE LANDSCAPE OF MAN (NEW YORK, NY: VIKINg PRESS, 1975), 96, fig. 142.

Given its specificity and the complex conceptual, technical, and cultural context of Marienbad, how might the reference to Ryoan-ji be interpreted? Was it simply a nod to Resnais's recent time in Japan working on Hiroshima, ${ }^{34}$ a souvenir hidden in plain sightlike the photo of Alfred Hitchcock that also appears briefly in Marienbad? ${ }^{35}$ of course, inserting a paragon of Japanese aesthetics into the core of a paradigm of French aesthetics touches on the anti-Cartesian aspect of the film, invoking Epstein. But its unsignaled appearance also alludes to the flashback in Hiroshima, where an image from wartime France intrudes on the heroine's experience of post-war Japan, with immediate dramatic implications. In the meanwhile, arranging human figures in imitation of Zen garden stones recalls Resnais's interest in representation, history, and the human body. Is it a clue, if not a key, through which to decipher "the lost secret of humanity", fulfilling Resnais's desire "to try to reassemble the scattered fragments of the universal culture that is being lost"? ${ }^{36}$ Does it map a new covenant between man, form, and the world? Or, is it a symptom of modern longing for a pre-modern past? Whatever its significance, the scene seems to balance on an overlap between the two defining paradoxes in Marienbadon one hand, knowing and not knowing; on the other hand, moving and not movinglinking to their other manifestations in the film (stagings of the time freeze effect, 
graphic matching of bodily forms across cuts, A confronting the photograph of herself) while remaining curiously apart.

\section{BIBLIOGRAPHY}

Bazin, André. "The Ontology of the Photographic Image”. Trans. Hugh Gray. Film Quarterly 13.4 (Summer 1960): 4-9.

Bergson, Henri. "Chapter 1: Of the Selection of Images for Conscious Presentation. What Our Body Means and Does". Matter and Memory. Trans. Nancy Margaret Paul and W. Scott Palmer. New York: Zone Books, 1991, 17-76.

Berthier, François. Reading Zen in the Rocks: The Japanese Dry Landscape Garden. Chicago: U of Chicago P, 2011.

Caruth, Cathy. Unclaimed Experience: Trauma, Narrative, and History. Baltimore: The Johns Hopkins UP, 1996.

Deleuze, Gilles. Cinema 2: The Time-Image. Trans. Hugh Tomlinson and Robert Galeta. Minneapolis: U of Minnesota P, 1989. [First French edition: 1985]

Epstein, Jean. “Le Cinéma et les au-delà de Descartes". La Porte ouverte 3 (1946). Reprinted in Écrits sur le cinema. Vol. 3. Paris: Éditions Seghers, 1975, 2-4.

Hamilton, Christopher. "Body, Memory, and Irrelevancies in Hiroshima mom amour". The Philosophy of Autobiography. Christopher Cowley (ed.). Chicago/London: U of Chicago P, 2015, 72-95.

Kline, T. Jefferson. "Rebecca's Bad Dream: Speculations on/in Resnais's Marienbad". Chapter 3. Screening the Text: Intertexuality in the New Wave French Cinema. Baltimore: The Johns Hopkins UP, 1992, 54-86.

Labarthe, André S., and Jacques Rivette. "Entretien avec Resnais et Robbe-Grillet". Cahiers du cinéma 123 (September 1961): 1-18.

Law, Jonathan. "Stasis and Statuary in Bazinian Cinema". Critical Quarterly 54.4 (2012): 107-122.

Luckhurst, Roger. The Trauma Question. London/New York: Routledge, 2008.

Monaco, James. “Conversations with Resnais: There Isn't Time Enough” [interview]. Film Comment 11.4 (July-August 1975): 38-41.

Reisz, Karel. The Technique of Film Editing. London/New York: Focal Press, 1958. [First edition: 1953].

Rivette, Jacques. Extracts of round-table discussion published as "Hiroshima, notre amour". Cahiers du Cinéma 97 (July 1959). Reprinted in Cahiers du Cinéma: The 1950s: Neo-Realism, Hollywood, New Wave. Jim Hiller (ed.). Cambridge, MA: Harvard UP, 1985, 59-70.

Robbe-Grillet, Alain. L'Année dernière à Marienbad: Roman. Paris: Les Éditions de Minuit, 1961.

Turim, Maureen. Flashbacks in Film: Memory \& History. New York/London: Routledge, 1989. 
Yamada, Shoji. Shots in the Dark: Japan, Zen, and the West. Chicago: U of Chicago P, 2011.

\section{NOTES}

1. This nomenclature comes from Alain Robbe-Grillet's ciné-roman, in which X corresponds to the character played by Giorgio Albertazzi in the film, A corresponds to that played by Delphine Seyrig, and M corresponds to that played by Sacha Pitoëff.

2. In Robbe-Grillet's scenario for Marienbad, published in 1961 as an eponymous ciné-roman, $X$ shows A not a photograph but a bracelet, a simple string of pearls with a clasp on which A's first name is engraved. See Alain Robbe-Grillet, L'Année dernière à Marienbad: roman, Paris: Les Éditions de Minuit, 1961, 130 and 136. The photograph was a late and consequential substitution.

3. The dialogue here and below follows the English subtitles in the Criterion Collection edition of the film.

4. $X$ says that he does not know and that it does not matter.

5. A seemingly life-size, photographic profile of film director Alfred Hitchcock appears in one brief shot in Marienbad, hanging on an ironwork grill in a back corridor. The image tags Marienbad as a mystery (however tongue-in-cheek the reference) while alluding to Hitchcock's practice of making cameo appearances in his own films.

6. See, for example, the account in T. Jefferson Kline, "Rebecca's Bad Dream: Speculations on/in Resnais's Marienbad", chapter 3 in Screening the Text: Intertexuality in the New Wave French Cinema, Baltimore: The Johns Hopkins UP, 1992, 54-86.

7. André Bazin's “Ontologie de l'image photographique” [Ontology of the Photographic Image] was published in 1958 as the first chapter of the first volume in a compendium of his writings, Qu'est-ce que le cinéma? 1. Ontologie et langage, Paris: Éditions du Cerf.

8. For a brief discussion of that tradition in relation to cinema, see Jonathan Law, "Stasis and Statuary in Bazinian Cinema", Critical Quarterly 54: 4 (2012): 107-122, especially 108-111. See also the texts by Annette Michelson, Robin Margaret Jensen, and Robin Cormack cited in Law's notes.

9. See Cathy Caruth, Unclaimed Experience: Trauma, Narrative, and History, Baltimore: The Johns Hopkins UP, 1996, 27. See, also, Roger Luckhurst, The Trauma Question, London/New York: Routledge, 2008, 149, citing Roland Barthes (2000), M. Hirsch (2001), and Laura Mulvey (2006); and 151, citing Saltzman (2006).

10. See Roger Luckhurst, The Trauma Question, London/New York: Routledge, 2008, 4, citing Cathy Caruth, "Introduction to Psychoanalysis, Trauma and Culture II," American Imago 48: 4 (1991): 417-424.

11. For example, shortly after showing A the photograph, $X$ tells her, "You've always been afraid. But I loved your fear that evening. I looked at you, letting you struggle a bit. I loved you. I loved you. There was something in your eyes. You were alive. Anyway...in the beginning... Try to remember. Oh, not at all. It was probably not by force. But only you know."

12. Henri Bergson, "Chapter 1: Of the Selection of Images for Conscious Presentation. What Our Body Means and Does", Matter and Memory, trans. Nancy Margaret Paul and W. Scott Palmer, New York: Zone Books, 1991, 68-69: "the past is essentially that which acts no longer, and [...], by misunderstanding this characteristic of the past, they [i.e., those who disagree with Bergson's argument] become incapable of making a real distinction between it and the present, i.e., that which is acting. No difference but that of mere degree will remain between perception and memory and neither in the one nor in the other will the subject be acknowledged to pass beyond himself".

13. Rivette was responding to the just released Hiroshima mon amour through reflections about Resnais's short film Toute la mémoire du monde (1956). See Jacques Rivette, in extracts of roundtable discussion published as "Hiroshima, notre amour", Cahiers du Cinéma 97 (July 1959), 
reprinted in Cahiers du Cinéma: The 1950s: Neo-Realism, Hollywood, New Wave, Jim Hiller (ed.), Cambridge, MA: Harvard UP, 1985, 60.

14. See, for example, Caruth, Unclaimed Experience, 26: "Confronting us with these two alternating shots, the film [Hiroshima mon amour] immediately imposes on our sight and understanding several fundamental questions: What do the dying bodies of the past-the dying bodies of Hiroshima-have to do with the living bodies of the present? And what is the role of our seeing in establishing a relation between these two sets of bodies? Introducing its filmic narrative through these problems, Hiroshima mon amour opens up the question of history, I would propose, as an exploration of the relation between history and the body". See, also, Christopher Hamilton, "Body, Memory, and Irrelevancies in Hiroshima mom amour", The Philosophy of Autobiography, Christopher Cowley (ed.), Chicago/London: U of Chicago P, 2015, 72-95, especially section 2, 75-85.

15. For a sustained account of this sequence and two other flashbacks in Hiroshima mon amour, see Maureen Turim, Flashbacks in Film: Memory \& History, New York/London: Routledge, 1989, 210-216.

16. See Luckhurst, "A genealogy of the traumatic flashback", The Trauma Question, 179-185.

17. "Il y a deux images, l'une qui lui est extérieure, l'autre intérieure. Mais du moment qu'elle les voit on peut dire de la même façon, il est très bien que le cinéma puisse les donner avec le même caractère de présent" (Labarthe and Rivette 10).

18. See Luckhurst, The Trauma Question, 182: "Split-second flashbacks, brought on by graphic matches, shock and disorient the viewer because they openly defy the conventions of continuity editing or the carefully framed and demarcated flashback sequence in classical Hollywood cinema [...]".

19. See Turim, Flashbacks in Film: Memory \& History, 216-217; Deleuze, Cinema 2, 122: "in Last Year at Marienbad we can no longer tell what is flashback and what is not".

20. In fact, this was a conflation of studio sets in Paris and the Nymphenburg and Schleissheim palaces near Munich, Germany.

21. In fact, this was an eighteenth-century view of Schloß Schleißheim onto which an image of the sculpture was superimposed.

22. In an interview with film critic James Monaco in 1975, Resnais cited Epstein's writings as an important, early influence on his work. See James Monaco, "Conversations with Resnais: There Isn't Time Enough" [interview], Film Comment 11. 4 (July-August 1975): 40.

23. Resnais studied film editing in the first class to graduate from the new Institut des hautes études cinématographiques (IDHEC) in Paris.

24. "I took a lot of things from his book. I am not ashamed to say that". In naming Epstein and Reisz as influences on his work, Resnais also identified only three others-"Griffith, of course, and Pudovkin and Eisenstein and their theories about editing"-who happened to be the three directors profiled by Reisz in the historical section of his book. Resnais would have known Reisz's book in English; although it was eventually translated into many other languages, beginning with Spanish in 1960, it was never published in French.

25. "Although the mechanical rules of cutting must be kept in mind, the decisive consideration at the junction of any two shots must be that the transition should be motivated by dramatic necessity" (227); "a series of dramatically apt cuts is generally to be preferred: it keeps the audience thinking and reacting continuously and never allows the presentation to become a passive record" (228).

26. To illustrate his point, Reisz discussed extracts from three films: Queen of Spades (Thorold Dickinson, 1949), The Lady from Shanghai (Orson Welles, 1948), and Tobacco Road (John Ford, 1941). See Reisz, 249-255.

27. See Deleuze, Cinema 2: The Time-Image, 2: "This is a cinema of the seer and no longer of the agent [de voyant, non plus d'actant]."

28. See note 12 . 
29. See note 12 .

30. In theatre, that technique-in which the action halts and, by implication, time freezes-is called the freeze frame.

31. That sense of transition is supported by the sound score, which shifts from measured tiptoes to dissonant chords.

32. See Berthier, 143-144.

33. See Yamada, 162.

34. Resnais spent two months in Japan, in August and September 1958, directing episodes of Hiroshima mon amour with a Japanese crew.

35. See note 5 .

36. See note 13 .

\section{ABSTRACTS}

According to film theorist and critic André Bazin, photography "derives an advantage" from its mechanical aspect: the process through which each object gives form to its own representation. In that way, photographs and other indexical media, including films, bridge past and present and have uncanny power. In Alain Resnais's film L'Année dernière à Marienbad (1961), photography is of special interest because of how those aspects relate to trauma. Confronting a photograph of herself traumatizes the principal female character, blurring the distinction between memory and perception and locating her not in uncertainty but at the intersection of knowing and not knowing. In a related way, editing and blocking haunt Marienbad by making evident the filmic paradox of moving and not moving. Forms of the human body are graphically matched across cuts in which other visual elements change, and performers stage the time freeze effect by holding their positions like statues or as if frozen. In those ways, the body develops a reputation for stability and coherence usually reserved for filmic space but here denied to it. Through such devices, and with an eye to transforming cinema, Resnais tested the relationship among representation, history, and the human body, an exploration sustained throughout his early films. In Marienbad, the two paradoxes pertinent to that interest - knowing and not knowing, moving and not moving - overlap in the iconic shot near the film's midpoint, in which the camera advances to reveal nine figures standing in the "empty" axis of a French-style garden and arranged enigmatically following a paragon of Japanese garden design: the meditation garden at Ryoan-ji, an important Zen temple in Kyoto, Japan.

Selon le critique et théoricien du cinéma André Bazin, la photographie "tire avantage" de son aspect mécanique, à savoir le processus par lequel chaque objet donne forme à sa propre représentation. C'est ainsi que les photographies et autres médias indexicaux, y compris les films, opèrent la jonction entre le passé et le présent et ont en cela un pouvoir étrangement inquiétant. Dans le film d'Alain Resnais, L'Année dernière à Marienbad (1961), la photographie présente un intérêt particulier du fait de la relation que ces éléments entretiennent avec le trauma. La protagoniste est traumatisée en découvrant une photo d'elle-même, ce qui brouille les frontières entre mémoire et perception et la place, non pas dans l'incertitude, mais à la croisée du savoir et $\mathrm{du}$ non-savoir. De manière similaire, la reconstruction mémorielle et les blocages hantent Marienbad en mettant en évidence le paradoxe cinématographique du mouvement et de l'absence de mouvement. Des formes de corps humain sont mises en miroir à l'écran dans des prises de vue 
où évoluent d'autres éléments visuels, et les comédiens mettent en scène cet effet de temps suspendu en se figeant tels des statues, comme s'ils étaient pétrifiés. À travers ces procédés, et avec à l'esprit l'idée de transformer le cinéma, Resnais testait la relation entre représentation, histoire, et corps humain, exploration déjà menée dans ses films précédents. Dans le film Marienbad, les deux paradoxes pertinents pour cette réflexion - le savoir et le non-savoir, le mouvement et le non-mouvement - se chevauchent dans le plan emblématique, très près du milieu du film, dans lequel la caméra s'avance pour révéler neuf silhouettes qui se tiennent dans l'axe "vide" d'un jardin à la française et dont l'agencement énigmatique correspond à la conception type du jardin japonais : le jardin de la méditation à Ryoan-ji, temple zen important de Kyoto, au Japon.

\section{INDEX}

Mots-clés: photographie, trauma, cinéma, mémoire, indexicalité, Histoire, corps humain, temps suspendu

oeuvrecitee Année dernière à Marienbad (L'), Hiroshima mon amour, Printemps tardif Keywords: photography, trauma, cinema, memory, indexicality, History, human body, time freeze effect

\section{AUTHORS}

\section{DAVID L. HAYS}

David L. Hays is Associate Head of the Department of Landscape Architecture at the University of Illinois at Urbana-Champaign, co-editor of the journal Forty-Five (http://forty-five.com), and founding principal of Analog Media Lab. Trained in architecture (M.Arch., Princeton University) and history of art (Ph.D., Yale University), his scholarly research explores contemporary landscape theory and practice, the history of garden and landscape design in early modern Europe, interfaces between architecture and landscape, and pedagogies of history and design. 